\title{
Concerns about the Euro and happiness in Germany during times of crisis
}

\author{
Adrian Chadi* \\ Institute for Labour Law and Industrial Relations in the European Union (IAAEU), University of Trier, 54286 Trier, Germany
}

Keywords:

Life satisfaction

Euro crisis

Currency

Political protest

Sensitive information

Media coverage

\begin{abstract}
A B S T R A C T
This empirical study investigates whether people's concerns about the Euro currency affect their life satisfaction. A minority of very concerned individuals appear to be unhappy, which cannot be explained by personality or other observable factors typically affecting well-being. As a novelty, this investigation exploits exogenous variation in reported concerns by using the intensity of media coverage on the euro crisis with its extraordinary events throughout the year 2011 as an instrument. Results from the application of several empirical approaches confirm that there is an effect from being concerned about the euro on people's satisfaction with life. A potential explanation is that political beliefs and euro-skeptic attitudes are at play and may trigger unhappiness as a consequence of a perceived lack of representation in German politics. In line with this argument, a regional analysis links the variation in unhappiness among concerned citizens to the actual votes for Germany's first major anti-euro party in the subsequent federal elections.
\end{abstract}

\section{Introduction}

The news headlines of 2011 offer a paradoxical picture of the situation in Germany. In the aftermath of the severe banking crisis with its economic repercussions, the country was economically in good condition and happiness appeared to be widespread among the citizenry. Meanwhile, the dominant topic of the year was the "concerns about the euro" (in German "Sorgen um den Euro"), as an ongoing sovereign debt crisis was omnipresent in the media. ${ }^{1}$ Despite thousands of people voicing their concerns in protests in other European countries during times of economic turmoil, for most Germans the potential problems related to the European Monetary Union (EMU) were not immediate problems. On closer inspection, however, there were indications, such as the rising anti-euro sentiment that started to evolve into a political movement during that time, suggesting that the topic did actually matter, at least to some particularly concerned people. ${ }^{2}$

\footnotetext{
* Tel. +49651201 4774; fax: +496512014742.

E-mail address: chadi@iaaeu.de.

1 The title of a December 2011 press release by the University of Hohenheim was: "The concern about the euro is the top issue of the year 2011". Based on their representative survey among people in Germany, researchers concluded that the euro crisis received more attention than events like Fukushima or the Arabic Spring. For additional background information, see Appendix B for a selection of media reports from that year.

${ }^{2}$ In a differentiated discussion, one needs to distinguish between the problems related to the EMU and the euro currency itself, For simplicity, the present paper follows the discussion in Germany by using the term "euro crisis" over alternative labels and leaves the broader discussion of the EMU (e.g., Katsimi and Moutos, 2010; Grüner, 2010; Mikosch and Sturm, 2012) and the crisis (e.g., Windels and Wendler, 2014; loannou and Stracca, 2014; Moro, 2014) with its underlying reasons to other researchers.
} 
This paper questions the narrative of the happy Germans during times of crisis by investigating whether being concerned about their currency has the potential to trigger non-monetary costs, measured in reduced life satisfaction. A second contribution is the discussion of the potential ways through which people may see their well-being affected and consequently may even reconsider their political views. By doing so, this study contributes to the discussion of the euro and the debt crisis often connected to it, while it also sheds light on the rise of a political movement. If concerns about the currency are capable of affecting people's life satisfaction in significant ways, a political response and increased willingness to protest are potential consequences, even if those who are affected constitute only a minority in a population that is overall passing happily through one of the most outstanding economic crises in recent times.

Apart from examples, such as the federal government's takeover of financial obligations, there were only few repercussions of the crisis for the country of Germany. One may even argue that the German economy benefitted from the euro crisis, as capital flows into the country increased. In line with that, the economic figures were very positive in Europe's largest economy, especially when compared to the situation in the southern euro countries. ${ }^{3}$ For Germans, the euro crisis of 2011 was an experience that clearly differed from financial crises with a discernable economic impact. In this context, recent empirical studies reveal nonmonetary effects in happiness resulting from the unemployment and income shocks during the financial crisis of 2008/2009 (Deaton, 2012) and show how the happiness of Europeans responds to recent banking crises (Montagnoli and Moro, 2014). Arguably, the absence of substantial changes in objective living standards for the people of Germany during the euro currency crisis motivates the analysis of subjective well-being data even more. Non-monetary indicators allow examining the role of concerns about a currency that is linked to severe problems in the media but not necessarily in the daily experiences of people in times of economic abundance. ${ }^{4}$

Previous research on subjective well-being suggests that concerns about one's own economic situation have the potential to substantially affect people (e.g., Knabe and Rätzel, 2011). Broader social problems may also be relevant but they play a different role than concerns about issues that are directly related to oneself. Whereas people may report being concerned about topics like crime or immigration, their life satisfaction is not necessarily affected by such global issues. Previous research about how the currency of the euro itself affects people in their well-being is limited to the euro changeover of 2002, for which Wunder et al. (2008) reveal a significant loss in well-being resulting from the implementation of the currency.

While the study here is motivated by the idea that subjective well-being is generally translatable and measurable in economic terms, the prime motivation comes from a more political viewpoint. ${ }^{5}$ Election outcomes after 2011 suggest that skepticism towards the euro currency and views about its economic role have been capable of inducing significant changes in the political landscape throughout Europe. Anti-euro views have been prevalent in the German public since the start of the discussion about the currency's implementation; yet, this political position has never received much support from German elites in politics, media, business, or science. With respect to the latter, a significant change occurred during the euro crisis as several professors of economics from German universities emerged to be the most prominent voices expressing concerns. As those views still had no significant representation in Germany's political spectrum, it was, in particular, some of those seemingly concerned economists who became politically active by being directly or indirectly involved in the founding of a party called the AfD (Alternative für Deutschland). ${ }^{6}$ The origin and unifying position of this political opposition is a straightforward anti-euro attitude, accompanied by the proposal to discuss re-introducing the German deutschmark (DM). The new party soon outperformed the long-term government party of the liberal democrats in election polls and almost entered the German Bundestag in the 2013 federal elections with the support of more than two million voters.

Following the description of data and empirical strategy (Section 2), the first part of the empirical analysis (Section 3) employs identification strategies used in previous happiness studies about the impact of subjectively perceived concerns. Results suggest strong negative effects in well-being from being concerned about the euro. The second part of the analysis (Section 4) constitutes a novelty in the context of research on people's worries and their well-being by making use of media data on the intensity of the euro crisis for the identification strategy. Thereby, an instrumental variable (IV) approach follows recent studies that exploit the quasi-randomness of the interview date as the basis of exogenous variation in the variable of interest (e.g., Kimball et al., 2006: Metcalfe et al., 2011; Schüller, 2012; Goebel et al., 2015). The discussion of results (Section 5) concludes that concerns about the

${ }^{3}$ Germany had a growth rate of $3.3 \%$ in 2011 , only slightly lower than the $4.0 \%$ growth rate a year earlier, according to official World Bank data. These strong increases in GDP could offset the contraction of the German economy in 2009 due to the banking crisis. Meanwhile, Italy and Spain had almost no growth in 2011; Portugal and Greece had negative growth rates. Unemployment increased in all these Mediterranean countries and reached levels going even beyond the high figures during the banking crisis. Contrariwise, unemployment in Germany continued to fall in 2011 . The unemployment rate of $5.9 \%$ was the lowest for the country in 20 years. For a broader discussion of the economic situation in the euro countries during the crisis, see Moro (2014).

4 For comprehensive discussions of both the potential and the validity of data on subjective well-being, see Frey and Stutzer (2002), Frey (2008) and Weimann et al. (2015). Many of the findings in this growing field, such as the negative impact of being unemployed (e.g., Clark and Oswald, 1994) or the importance of both absolute and relative income (e.g., D'Ambrosio and Frick, 2012) are consistent over different data sets and across different countries. Note that in line with many other studies in this field, the discussion here treats the terms happiness, life satisfaction and (subjective) well-being interchangeably.

5 To illustrate the economic importance, studies in this field often provide a transformation of well-being effects into equivalent monetary figures (e.g., Carroll et al. 2009; Lüchinger, 2009; Lüchinger and Raschky, 2009; Kountouris and Remoundou, 2011). While such transformation may give the reader helpful information, the exact calculation of the monetary equivalent is not trivial. See, e.g., Oswald and Powdthavee (2008), Powdthavee (2010) and Frijters et al. (2011) about the challenge to identify the effect of income on well-being.

6 While the party had its origins in the euro crisis, it was officially founded in 2013. See the AfD federal elections program (2013) for the political positions regarding economic issues and the topic of currency in particular.

${ }^{7}$ The final AfD vote of $4.7 \%$ was slightly below the threshold of $5 \%$ needed to win seats in Germany's main legislative body, showing that the party was elected only by a minority of German voters in 2013. Note that the country's total population is approximately 80 million people of which approximately 62 million adults are at least 18 years of age and are eligible to vote in federal elections. 
euro affect the well-being of people. As a final step, an analysis based on regional data links the unhappiness of the concerned citizens to the federal election results of Germany's first major anti-euro party two years later. The finding of a strong link supports the conclusion (Section 6) that data on subjective well-being does not only contain information about non-monetary implications of economic developments but also has the potential to predict concrete and objectively relevant outcomes, such as election results.

\section{Empirical framework}

\subsection{Data}

The German SOEP study is a broad and representative survey that provides data from thousands of annual interviews (Wagner et al., 2007). Fieldwork starts at the beginning of each year and is carried out on all days of the week. The majority of interviews are conducted between late winter and early summer (see Fig. 1), as interviewers have a pre-defined period over a couple of months to arrange the interview dates. As participation in the SOEP is voluntary, respondents can reject dates suggested by the interviewer but are then offered new dates. Scheduling of dates usually takes place several days in advance.

The data are obtained through different survey modes, including personal interviews that are conducted by interviewers in face-to-face situations and questionnaires that the participants fill out while the interviewer is constantly or partially present in the room. The questionnaire can also be filled out without assistance by an interviewer, which can happen when a household member is not at home during the interviewer's visit or when contact between the data collecting agency and a respondent is generally only via mail. While interviewers have a lot of freedom with respect to interview timing, they were initially asked to give preference to the survey mode of oral interviewing. Demonstrated by the fact that in recent SOEP waves only about half the interviews have been done in face-to-face situations, the interviewers oftentimes make use of the opportunity to let respondents do the questionnaires on their own and obtain the completed documents later. While this option is very attractive for interviewers, as they do not have to spend their time doing oral interviews, the justification from the perspective of the survey designers is maximizing participation. Despite the effort to tackle attrition through such a multi-faceted survey design, over the years some participants still exit the panel. Thus, from time to time, the data collectors invite new samples of people to participate in the survey, allowing annual participation numbers to remain at high levels.

To measure subjective well-being, happiness researchers typically exploit the life satisfaction question in the SOEP where interviewees have to assess their situation on a scale ranging from 0 ("completely dissatisfied") to 10 ("completely satisfied"). The exact wording is: "How satisfied are you with your life, all things considered?" The suspected determinant of well-being and key variable of interest here is the people's concerns about the euro currency. This question is not part of the standard topics that are observed annually regarding what might be of concern to the German people. This question block starts with: "What is your attitude towards the following areas - are you concerned about them?" The questionnaire provides three categories: "Very concerned”/“Somewhat concerned"/"Not concerned at all". The list includes topics of a general social kind (e.g., crime, environmental protection, general economic development) as well as private issues (e.g., own economic situation) and is occasionally modified from one year to the next by the survey designers. Most importantly, respondents were asked at the time of euro implementation about their concerns with respect to the "Introduction of the Euro in place of the D-Mark." This allowed analyses on the new currency when it was first implemented

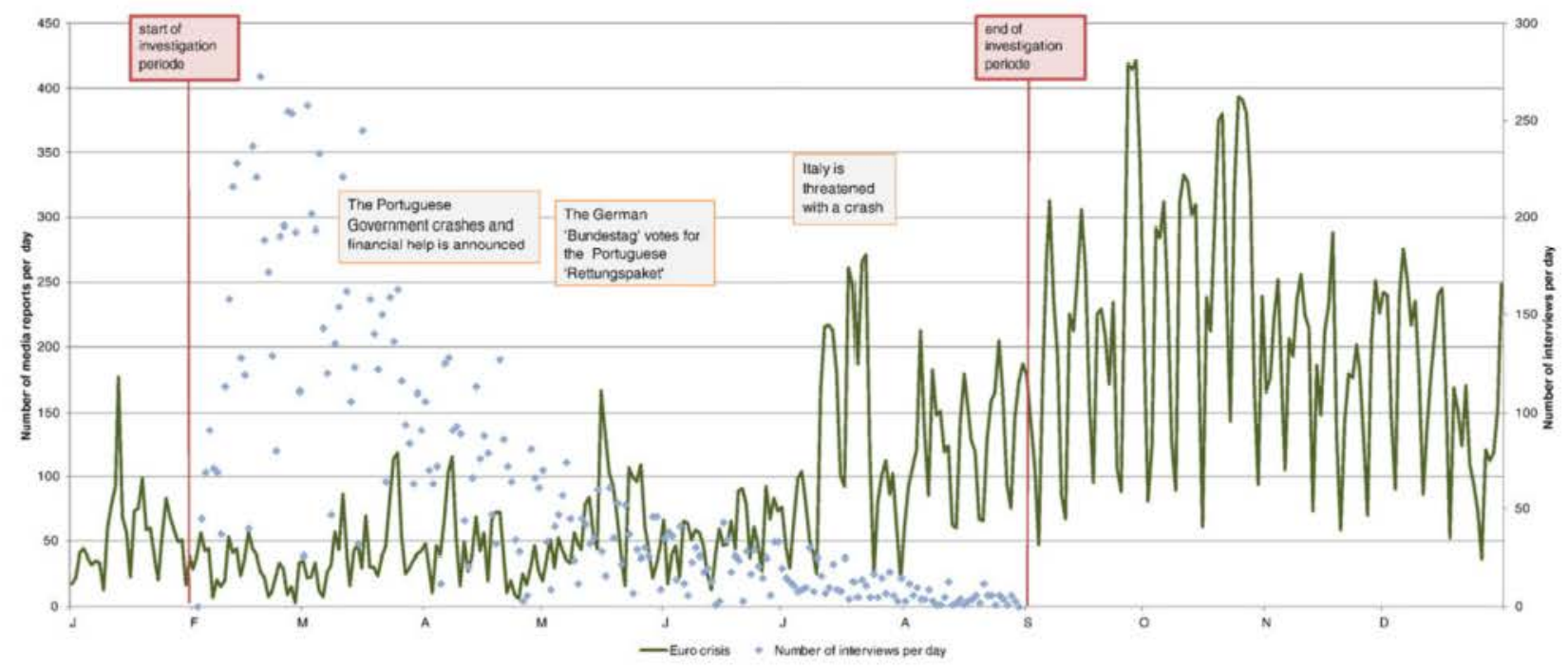

Fig. 1. Euro Crisis in the German media. Notes: the (green) graph shows for each day of 2011 the number of media reports containing the term "euro crisis" according to LexisNexis, whereas (blue) dots show the number of completed SOEP questionnaires per day within the investigation period from February to August. 
(e.g., Isengard and Schneider, 2007). Faced with the economic turmoil in Greece, which reached its first heights in 2010, the survey organizers put this item back onto the list, using the same wording as before to facilitate comparison of responses and longitudinal analyses.

Following previous investigations in the context of concerns and well-being (see, e.g., Goebel et al., 2015), binary variables allow for a reasonable distinction between people who are very concerned about a topic, as the highest category, and the somewhat concerned/no concern categories. This makes sense because only strong concerns are expected to matter for people's life satisfaction. Previous studies have analyzed well-being effects of tragic events, such as nuclear disasters, and mostly found no effect in life satisfaction levels, but instead in the people's worries about the specific topic, such as environmental concerns (e.g., Berger, 2010). This underlines that happiness is generally quite stable and even remarkable tragedies do not necessarily change people's satisfaction with their lives, despite outstanding media coverage.

The SOEP offers a broad set of data about people's socio-demographic background, economic aspects, recent life events, and much more. Information on objective health problems can also be included in the analysis. Furthermore, the SOEP wave of 2009 provides data on people's personality traits in the form of the Big Five concept. This allows considering personality in a comprehensive way via the traits extraversion, agreeableness, conscientiousness, neuroticism, and openness (McCrae and Costa, 1987). By assuming stability in traits, data on these five factors can be transferred to the data from the 2011 wave.

\subsection{Empirical strategy}

An intensely discussed issue in happiness research is the role of people's personality, which Ferrer-i-Carbonell and Gowdy (2007) consider to be the key factor in the context of concerns and well-being. As given individual traits are likely to determine both happiness and the probability of being concerned, the authors are confident to address potential identification concerns by exploiting available proxies for personality in their British survey data. The SOEP data allow tackling this issue similarly by means of observable information that promises to measure traits in a direct way. Following these considerations, the first empirical approach constitutes a cross-sectional regression analysis that exploits the richness of the data by considering both personality via the Big Five measures and a large number of the observable determinants of well-being. Many of those are also expected to be related to whether people are concerned about the euro or not. For instance, the literature suggests that higher education goes along with a more positive view on the topic of the euro (e.g., Routh and Burgoyne, 1998). Consequently, the first empirical model includes people's concerns, a set of personality measures, and a large array of control variables $(X)$ reflecting the background of the people and also the survey situation (see Section 2.4):

$$
\text { SWB }=\beta \text { Concerns }+X^{\prime} \gamma+\text { Personality' } \eta+\varepsilon
$$

Instead of solely relying on the 2011 data, the re-incorporation of exactly the same question from the time of the euro changeover allows establishing a panel setting and applying another approach that is commonly used in happiness research. In this case, fixed personality traits are dealt with indirectly by considering an individual fixed effect $(\mu)$ in a longitudinal analysis. Also a time effect $(\tau)$ is included in this second empirical model as follows:

$$
\mathrm{SWB}=\beta \text { Concerns }+X^{\prime} \gamma+\tau+\mu+\varepsilon
$$

The last SOEP wave from the time of the changeover that included the key question on concerns about the euro currency is from 2003. Combining the data with those of 2011 is linked to a loss of observations because the condition for each person to be included in this longitudinal sample is to be observed over a long period. Note that for the sake of representativeness, survey-weighting factors are routinely included in all analyses to align demographics in the data (cross-sectional and longitudinal) with the population. Another technical issue is the question of which method to use when being confronted with ordinal data. The analysis here follows most of the studies in happiness research and employs linear regressions. ${ }^{8}$

Both of the standard approaches reflected in models (1) and (2) rely on assumptions that previous research in the field routinely made. The first model requires the comprehensive observation of all relevant influencing factors in the relationship between wellbeing and concerns about the euro in order to identify causal effects. The second model requires observing all time-varying factors, as otherwise the effect would not necessarily be identified in an accurate way. These strong assumptions motivate the introduction of a third empirical model. The idea behind the following approach is to use the euro crisis to establish a valid and relevant instrument for people's concerns about the euro currency. Specifically, the intensity of recent media coverage about the crisis on a given (interview) date is the exogenous factor in the first stage of the IV design, leading to the following model:

$$
\begin{aligned}
& \text { Concerns }=\theta \text { Crisis }+X^{\prime} \gamma_{1}+v \\
& \text { SWB }=\beta \text { Concerns }+X^{\prime} \gamma_{2}+\varepsilon
\end{aligned}
$$

\footnotetext{
${ }^{8}$ Researchers commonly refer to the general discussion in Angrist and Pischke (2008) or to the field-specific contribution on methodology in happiness research by Ferrer-i-Carbonell and Frijters (2004).
} 


\subsection{Using the euro crisis as an instrument}

Since the people in Germany receive information about political and economic developments primarily through the media (Hölig and Hasebrink, 2015), the idea is to measure the intensity of the crisis as the exogenous source of variation by the quantity of media reports about this topic as an objective indicator. As for other media-based analyses (e.g., Groseclose and Milyo, 2005; Lamla and Lein, 2014; 2015), the collection of media data takes place via LexisNexis. ${ }^{9}$ Running its search engine with the term euro crisis for every day of the year 2011, LexisNexis computes the number of media reports that contain this particular word. The aggregated number of reports represents an objective reflection of the varying intensity of the euro crisis. These figures, serving as a crisis indicator, are then merged with the SOEP data on the basis of the exact interview dates. The actual numbers of media reports containing the term euro crisis vary from just three on February 27, to several hundred. The primary reason for this variation is the occurrence of several outstanding events that took place throughout the year. This type of political development can be expected to trigger reactions in the concerns among the citizens of Germany when asked about the euro currency similar to, for instance, nuclear disasters that are known to raise concerns about environmental problems in similar research settings based on interview date identification (e.g., Berger, 2010). ${ }^{10}$

Fig. 1 depicts the raw data from LexisNexis that is the daily number of media reports about the euro crisis for each of the 365 days of 2011. The illustration shows some peaks in crisis intensity, a strong day-to-day variation, a basic trend that suggests a steady increase in the emergence of the "euro crisis" in the German media, and also a lot of noise in the final months of the year. The latter is not an issue for the following analysis due to the limited availability of actual SOEP data. A reasonable step in this context is to restrict the period of investigation to the time when the interviews were actually carried out in that survey year (Wunder et al., 2008). Limiting the time window to the months from February to August results in almost no loss of data because less than a hundred of these out-of-order interviews took place in all other months combined in 2011.

A plausible explanation for the steady increase in media reports on the euro crisis throughout the year is that this trend reflects a media artifact connected to the establishment of a new term rather than the actual development of the crisis and its intensity. The term "euro crisis" first needed to be established as a key word among media people, and then it was used generally more than before. Furthermore, as more events take place, the more journalists can and will refer to previous events while writing about other issues. This can explain why the measure gives extremely high numbers for September and October in the absence of any significant event. A simple way to deal with such an artificial increase in crisis intensity is adding a trend to the regression equation. ${ }^{11}$

Another important facet of analyzing media-triggered responses to a political development is the delay in the impact of news events on the people. For instance, an SOEP interview takes place during the day, while the bailout of a far-away country is announced in the evening. First, many survey participants may not have received the relevant information of that day while filling out the questionnaire. Second, people do not necessarily realize the implications of such events immediately, but they eventually are informed as a result of the numerous debates and reports on television or in personal discussions with others. ${ }^{12}$ Hence, the actual magnitude of the impact of a political event is expected to reach its peak days after the event itself when political discussions and the spreading of information have fostered people's concerns. Consequently, it makes sense to aggregate the media coverage intensity from the last few days prior to the interview. This may also help smoothing the day-to-day variation and dealing with weekday-specific phenomena in media coverage, such as a potential weekend effect. Note that research on the role of survey methodology suggests that the weekday of the interview might play a direct role in measuring well-being (Taylor, 2006), which leads to another important topic with high relevance in this context.

\subsection{Survey-specific aspects}

Survey-related aspects concerning the interview situation can affect how people give responses. This topic is of special importance in the measurement of subjective well-being and has received increased attention in recent years. Relevant factors are, for instance, a respondent's experience with being interviewed, typically measured by the years someone has participated in a panel study. Panel experience commonly runs in parallel with lower reported life satisfaction (Chadi, 2013; van Landeghem, 2014). The survey factor of the weekday on which the questionnaire was done may play a double role in this research context. Controlling for it in the main life satisfaction analysis appears to be necessary if there is an inherent and significant measurement bias coming from day-to-day differences in the way people report well-being, which however is debated controversially (Tumen and Zeydanli, 2014).

\footnotetext{
${ }^{9}$ This data bank contains major German publications, like Die Welt or Der Spiegel, that are included with their print and online products in addition to agency reports and other sources of news media information. To avoid an arbitrary decision, the analysis considers all news media sources combined that are available in this data bank. ${ }^{10}$ See also Becchetti et al. (2011) who exploit news coverage in order to discuss how bilateral relations between countries affect migrants' well-being in Germany. 11 Another option is to clean the instrument from its trend before it enters the analysis. Such trend adjustment can be implemented by first determining the linear increase in media reports throughout 2011 and second reducing the number of reports for each day by the slope parameter times the number of the day, starting with one for January 1. Note that findings from this approach are very comparable to those presented here. Note also that, for illustration purposes, the media report numbers used in the following analyses are always counted in 100 reports.

${ }^{12}$ An important phenomenon in the context here is the large number of political talk shows on television, which millions of Germans watch and which often take place in the days following the actual political developments. Note that the list of media outlets included in LexisNexis does not contain television programs.
} 
Another survey factor that is of great importance in the following analysis is the interview mode. In happiness research, it is helpful to control for the inherent measurement bias expected to come from the interviewer's presence, which is known to significantly affect self-reported happiness (Conti and Pudney, 2011). The intuition is that respondents are less likely to report unhappiness in the presence of interviewers compared to when they fill out a questionnaire on their own because living an unhappy life is sensitive information. One distinction on the basis of the given interview modes in the SOEP is to differentiate between modes in which respondents provided data by completing the survey on their own and face-to-face modes in which data were obtained by oral questions of the interviewer. These oral interview modes are paper and pencil (PAPI) and computer-assisted personal interviewing (CAPI). In contrast, it is very unlikely that the interviewer affects response behavior on sensitive questions in modes without any interviewer presence. It is also rather unlikely that this happens in mixed modes where the interviewer is present but the questionnaires are partially or fully done in self-completion. Still, for sensitivity checks, the latter data from mixed modes is excluded in the following analyses, whereas both the first empirical part (Section 3) and the IV analysis (Section 4) are conducted primarily with all data from self-completed questionnaires.

As a specialty of the research context here, a social desirability phenomenon may not only be relevant for the outcome variable of reported happiness but plausibly might also affect self-reported concerns. The standard example in this context is when people have to answer whether they are concerned about immigration (Janus, 2010), which also has been discussed as a sensitive issue explicitly with respect to the question in the SOEP (Wagner and Schräpler, 2001). Rejecting the supranational currency of the euro, favoring the former currency of the DM, having generally more nationalistic views-all these can be considered as sensitive as well. In the political atmosphere of 2011 and also in the election year of 2013 with the appearance of the new party AfD, expressing anti-euro and pro-DM attitudes was arguably not in line with a desire to report what was socially desirable. In particular, the German people are typically very careful to avoid political ideas that can be portrayed as nationalistic, likely a result of the country's history and the experiences of the 20th century. ${ }^{13}$

\subsection{Transmission channels}

According to Ferrer-i-Carbonell and Gowdy (2007), there are two interpretations of why people may be affected in their life satisfaction when being concerned about a broad social topic. One can be described as reflecting people's awareness, whereas the second relates to attitudes. In the context of concerns about the euro currency, it is plausible to expect that some people are aware of potential economic uncertainties. A feeling of economic insecurity and fears about how the future will look economically may lead to a lower level of well-being. ${ }^{14}$ To test the potential role of this argument, the empirical model can be expanded with the available information on people's general economic concerns as well as on the concerns regarding their own economic situation.

The other interpretation is that people's attitudes are working as a transmission channel so that the people who report being strongly concerned about the euro have a negative view on the whole concept of supranational currency and are frustrated about the political situation. Arguably, the people in Germany with an anti-euro stance cannot feel represented in this point by the major German parties that typically constitute the federal government and more or less support policies that are advertised as necessary to support the euro currency. A more technical argument favoring the attitude interpretation is that both framing and wording of the question may have increased the probability that respondents express anti-euro sentiment when reporting to be very concerned about the euro. In particular, the reference to the DM that is included in the wording might provoke euro-skeptical individuals to respond.

The subsequent elections in the time after 2011 offer an interesting opportunity to find out more about the plausibility of the more political interpretation. The idea is to examine the potential link between people's dissatisfaction with politics concerning the euro currency and the political reaction that may have emerged in connection to it. If the political interpretation of the euro-related unhappiness is accurate, the uncomfortable situation of feeling unrepresented in German politics may serve as the trigger for people to start participating in the anti-euro protest and the formation of the new party AfD.

Using regional indicators that researchers can obtain upon request from the SOEP, the data sample for the whole of Germany can be broken down into 96 regional policy regions (ROR). These clusters have an average population of slightly less than a million inhabitants, and on average a hundred SOEP interviewees are in each one. At such a regional level, differences in the unhappiness among people concerned about the euro can be linked to actual voting outcomes using both a sizable number of regions

\footnotetext{
${ }^{13}$ As one of many expressions of social disaffirmation, many of the $A f D$ posters were vandalized during recent elections, often aimed at characterizing their political agenda as nationalistic extremism and their personnel as potential Nazis (Tageszeitung online, August 13, 2013; Augsburger Allgemeine, May 14, 2014; Welt, May 23. 2014). Further examples of the stigma linked to this political movement are the many cases of disturbances, and even violent attacks during campaigning (Tagesspiegel online, August 5, 2013) and at rallies (Süddeutsche online, August 14, 2013; Zeit online, August 24, 2013; Stuttgarter Zeitung, January 13, 2014; Sächsische Zeitung, May 10, 2014), the willful destruction of famous party members' private property (Berliner Morgenpost online, September 19, 2013), and the open refusal by the major parties to cooperate with the AfD (Focus online, September 19, 2013; Huffington Post Deutschland, May 23, 2014; Handelsblatt online, August 20, 2014), topped by the announcement of the parliamentary leader of the largest Bundestag faction, Volker Kauder, to not even discuss politics with their representatives (Süddeutsche online, May 29, 2014).

14 Wunder et al. (2008) argue in their study on welfare effects of euro implementation that, as a consequence of perceived problems with their currency, people might change consumption behavior, which can lead to suboptimal decisions and thus lower well-being. An uncertain economic future can affect current consumption behavior, e.g. via job loss fears (Stephens, 2004) or inflation expectations (Stix, 2009).
} 


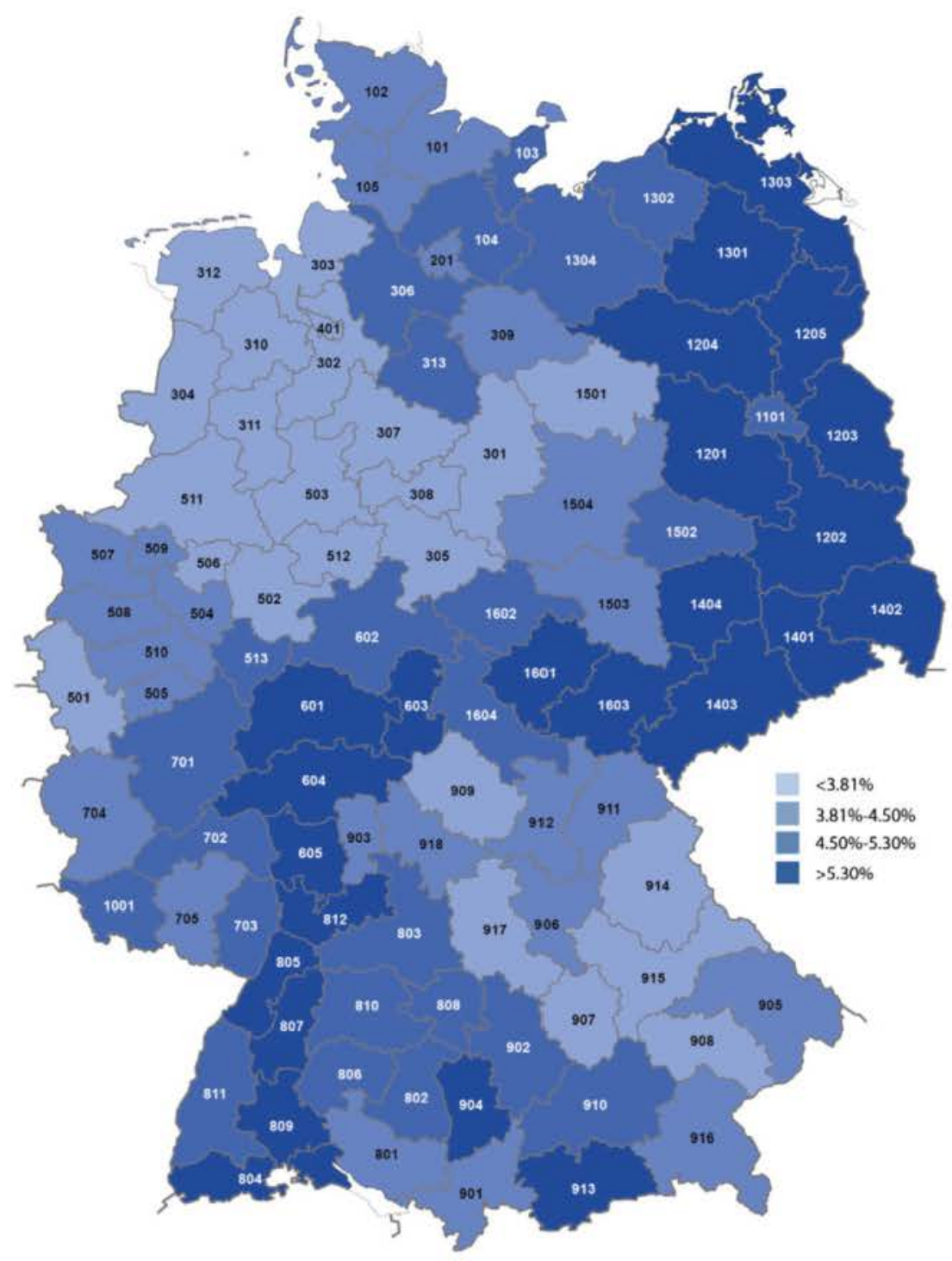

Fig. 2. AfD federal election results of 2013. Notes: the map shows the regional AfD voting shares for all 96 ROR (numbered from 101 to 1404 ) according to the official federal election administration data. The four different colors represent a quartile-based categorization. The increasing dark blue color indicates a higher regional voting share in the 2013 election outcomes. The creation of this map benefitted from a template provided by Germany's Federal Institute for Research on Building, Urban Affairs and Spatial Development.

and also sufficient observation numbers per ROR to allow for a meaningful analysis. Fig. 2 shows graphically how the voting shares of the anti-euro party AfD differed regionally in the federal elections of 2013. The darker color indicates a larger electoral success for the protest party.

Looking at the actual numbers, the AfD received their best result in the ROR (1402) Upper Lusatia-Lower Silesia (Oberlausitz-Niederschlesien) with a voting share of $7.7 \%$, far beyond the official election result of $4.7 \%$ for the entire country. ${ }^{15}$ The lowest support as expressed in voting shares came from the ROR (304) Emsland with only $2.5 \%$ of the valid votes being $A f D$ votes. This huge discrepancy in electoral success between a far east and a far west region suggests a potential disparity along the lines of the former separation of the country, but only at first glance. The graphical illustration in Fig. 2 rejects the notion of an East-West as well as a potential rich-poor disparity. In fact, many of their best results for

\footnotetext{
15 The complete data set with all election figures is available from the author upon request, as are all further results that are not shown but are mentioned in the paper.
} 
Table 1

Life satisfaction and concerns about the euro: regression analysis.

\begin{tabular}{|c|c|c|c|c|c|c|}
\hline \multirow{2}{*}{ Method: } & \multicolumn{3}{|c|}{ Pooled regression } & \multicolumn{3}{|c|}{ Fixed-effects regression } \\
\hline & (1) & (2) & (3) & (4) & (5) & (6) \\
\hline Concerns about the euro & $\begin{array}{l}-0.582^{*+*} \\
(0.083)\end{array}$ & $\begin{array}{l}-0.523^{* *+} \\
(0.086)\end{array}$ & $\begin{array}{l}-0.416^{* * *} \\
(0.087)\end{array}$ & $\begin{array}{l}-0.336^{* * *} \\
(0.109)\end{array}$ & $\begin{array}{l}-0.321^{* * *} \\
(0.109)\end{array}$ & $\begin{array}{l}-0.318^{* * *} \\
(0.110)\end{array}$ \\
\hline \multicolumn{7}{|l|}{ Other general concerns } \\
\hline Economic development & & $\begin{array}{l}-0.221^{* * *} \\
(0.070)\end{array}$ & $\begin{array}{l}-0.029 \\
(0.074)\end{array}$ & & $\begin{array}{l}-0.151^{*} \\
(0.079)\end{array}$ & $\begin{array}{l}-0.078 \\
(0.081)\end{array}$ \\
\hline Environment & & & $\begin{array}{l}0.188^{* * *} \\
(0.072)\end{array}$ & & & $\begin{array}{l}0.221^{* i *} \\
(0.086)\end{array}$ \\
\hline Peace & & & $\begin{array}{l}0.026 \\
(0.068)\end{array}$ & & & $\begin{array}{l}0.036 \\
(0.081)\end{array}$ \\
\hline Crime & & & $\begin{array}{l}0.051 \\
(0.070)\end{array}$ & & & $\begin{array}{l}-0.099 \\
(0.089)\end{array}$ \\
\hline Immigration & & & $\begin{array}{l}-0.072 \\
(0.083)\end{array}$ & & & $\begin{array}{l}0.168^{*} \\
(0.098)\end{array}$ \\
\hline Xenophobia & & & $\begin{array}{l}0.114 \\
(0.077)\end{array}$ & & & $\begin{array}{l}0.087 \\
(0.103)\end{array}$ \\
\hline \multicolumn{7}{|l|}{ Individual-specific concerns } \\
\hline Own economic situation & & & $\begin{array}{l}-0.971^{* * *} \\
(0.084)\end{array}$ & & & $\begin{array}{l}-0.597^{* * *} \\
(0.095)\end{array}$ \\
\hline Observations & 7148 & 7148 & 7148 & 7148 & 7148 & 7148 \\
\hline $\mathrm{R}^{2}$ & 0.239 & 0.242 & 0.281 & 0.096 & 0.098 & 0.125 \\
\hline Set of control variables & Yes & Yes & Yes & Yes & Yes & Yes \\
\hline Big Five personality & Yes & Yes & Yes & No & No & No \\
\hline Individual fixed effects & No & No & No & Yes & Yes & Yes \\
\hline
\end{tabular}

Notes: dependent variable is life satisfaction on a 0 to 10 scale. Variables for concerns are binary indicators that always represent "very concerned" responses. Set of controls includes variables for the survey year, gender (only pooled), migration background (only pooled, number of variables is 2 ). age (2, pooled: 3 ), nationality (4), religion (3), education (4), employment (6), retirement, income, house ownership, housing conditions (4), household composition (3), family status (4), partnership, health status (3), recent life events (6), federal state (15), year in the panel (26), and interview mode (3). Big Five personality is a set of 10 binary variables for high and low extraversion, agreeableness, conscientiousness, neuroticism, and openness. Standard errors are clustered at the individual level. Survey weights are used. All analyses in this table use data collected via self-completed questionnaires. SOEP data from 2003 and 2011 (with Big Five measures from 2009 ) are used.

$* p<.10$.

$* * 0<01$.

the AfD came from the wealthy areas in the southwest of Germany. Motivated by this puzzling illustration and the question of what is behind the rise of anti-euro protest in the heart of Europe, the merger of this election data with the SOEP data allows testing the potential link between $A f D$ votes and the unhappiness of people who reported to be very concerned about the euro two years before.

\section{Standard cross-sectional and longitudinal analysis}

Table 1 presents the results from applying model (1) and shows a significant difference in life satisfaction between people who report being very concerned about the euro and those who do not in column (1). This holds when controlling for a variety of important determinants for people's subjective well-being. Yet, neither the personality traits nor the objective indicators of health status nor socio-economic characteristics can fully explain the significant gap in well-being. Assuming that the large set of control variables used in the specification sufficiently captures all factors relevant to the relationship of happiness and concerns about the euro, the impact of the latter can be considered as the reason for reduced well-being.

The next step consists of expanding the empirical model with indicators for strong concerns about other issues. The variable of being very concerned about the general economic development, added in column (2), indicates a highly significant effect that is as large as the well-being effect of the main variable of interest. However, the effect of being concerned about the currency remains strong, which conflicts with the notion that perceived problems with the euro affect people only through their economic concerns. While the state of the economy seems significant to people's well-being, the results suggest that concerns about the euro constitute an independent factor on its own.

Column (3) shows the results when adding further concerns of broader social issues, which mostly turn out to be insignificant for people's happiness. A comparison makes clear that a negative link between such types of social concerns and life satisfaction is not the necessary outcome. As the ultimate test for the potential transmission channel of feeling economically insecure due to perceived problems with the euro currency, the specification also includes a variable for people's concerns with their own economic situation. This factor is highly significant to people's well-being, as expected, but even after controlling for it there is still 
a significantly negative effect on well-being from being very concerned about the euro. Concerns about the general economic situation seem to matter only for people who also feel insecure about their own situation, as the significance of the effect in the second row disappears.

As shown in the columns (4) to (6) of Table 1, results from the panel analysis present a similar picture compared to those in the cross-sectional analysis. First and foremost, the significant effect derived from applying model (2) on the longitudinal sample further supports the hypothesis that individuals concerned about the euro suffer in terms of reduced life satisfaction. In fact, the only significantly negative factor among the concerns about broader social issues is again the worries about the euro, whereas general economic concerns become insignificant when the individual economic insecurity is controlled for. The test for a potential transmission channel of economic insecurity again cannot reject the idea that it is more than just economic problems that explain the effect of being concerned about the euro. ${ }^{16}$

To summarize, the evidence in this section suggests an effect of concerns about the euro on well-being. Assuming that the key factor in the relationship between worries and well-being is personality, it is plausible to conclude that people suffer because of their concerns about the euro currency. Yet, this is an optimistic assumption, especially if the relationship of interest is between two subjective variables. Moreover, the time period between the observations is relatively long in the longitudinal analysis, so that unobservable factors may have changed over time. ${ }^{17}$ While one may argue that the results in the within-individual analysis are all the more impressive, there is reason for another empirical step.

\section{Instrumental variable analysis}

\subsection{First stage and establishment of the IV}

This subsection discusses the role of the first stage when using the data from LexisNexis. This will demonstrate how the available exogenous variation in people's concerns about the euro is exploited to establish an instrument that is both valid and strong. As illustrated earlier, there are several aspects that require attention, such as the potential delay in the impact of news events and socially desirable reporting. Findings in the previous section suggest a significant reduction in individual life satisfaction when people are concerned about the euro currency that cannot be explained by perceived economic worries alone. If indeed the political frustration of more euro-skeptical individuals is the explanation for the observed unhappiness, this is a particular issue for an IV design that attempts to exploit the ramifications of current political developments in survey data. The exogenous variation with regard to the euro crisis may indeed affect people in their views, yet it is possible that they refuse reporting private and sensitive opinions in the presence of interviewers. Instead, face-to-face situations might provoke some interviewees who actually do not care about the topic to react to such a question as they connect the topic to a current wave of media coverage. Such interviewees, without true concerns about the euro in economic or political regards, would hinder any identification of the impact on people who are truly suffering under the circumstances regarding the euro currency.

Table 2 shows how media coverage measured in the number of reports on the euro crisis of the current day, the last day, the second last day, etc. is linked to people's responses. All panels (A) - (C) show significant increases in the likelihood of whether people are concerned about the euro when recent news coverage is more intense. Interestingly, the euro crisis coverage of the survey day is not strongly linked to the self-reported concerns, but with an increasing delay, the strength of the exogenous influence swells. It reaches its peak two and three days later. Afterwards, the crisis stimulus then seems to fade with time. The pattern becomes more pronounced when weekday variables are introduced to the model, as shown in the middle panel (B), and even more so when a day of the year variable capturing a linear trend is introduced in the lower panel (C). Assuming that both aspects need to be controlled for because they reflect media artifacts, the following IV analysis considers these factors as well. ${ }^{18}$

While the sample analyzed in Table 2 includes data from self-completed questionnaires, the picture looks different in data obtained when interviewers conducted face-to-face interviews. The weaker significance observed in that type of data (see Appendix Table A.1) suggests that when asked orally not many interviewees actually respond to the political development, independent of the important question whether they report serious concerns or not. In contrast, the crisis coverage of the last days is strongly related to the reported concerns about the euro in the other half of the data.

To ensure having a strong IV based on these data and to provide sensitivity checks, the idea in the following is to establish different versions of the instrument that in one way or the other aggregate the report numbers over the last days. The first IV (IV1) is a one-week moving average, which adds up the number of reports on the crisis from the day of the interview plus the last six days, divided by seven. A second IV (IV2) and a third IV (IV3) both pick up the observation of the fading

\footnotetext{
${ }^{16}$ Variations of the data set lead to the same conclusions. Dropping mixed interview modes from the analyses goes along with a sizable loss of data due to the requirement of being observed in both yearly samples. Still, the results are almost unchanged compared to those presented in Table 1 . The findings also hold when the sample is expanded with data from oral face-to-face interviews, though the magnitude of the euro concerns effect declines.

17 Deeper analyses of observable compositional changes show no convincing evidence that attrition from 2003 to 2011 is related to whether people are politically or economically concerned. A significant determinant of willingness to participate seems to be the self-reported level of life satisfaction (Chadi, 2014). If anything, however, a higher chance of panel exit among unhappy people should frustrate and not foster the detection of negative effects in people's life satisfaction, as presented here in this study.

${ }^{18}$ Note that a second trend variable for a possible exponential increase of media coverage is always insignificant.
} 
Table 2

Concerns about the euro and media coverage of the euro crisis.

\begin{tabular}{|c|c|c|c|c|c|c|}
\hline Specification: & (1) & (2) & (3) & (4) & (5) & (6) \\
\hline Lag: & None & 1 day & 2 days & 3 days & 4 days & 5 days \\
\hline \multicolumn{7}{|l|}{ A) } \\
\hline Euro-crisis intensity & 0.025 & $0.045^{*}$ & $0.093^{* * *}$ & $0.100^{* * *}$ & $0.075^{* *}$ & 0.053 \\
\hline (trend adjusted) & $(0.028)$ & $(0.026)$ & $(0.023)$ & $(0.024)$ & $(0.034)$ & $(0.037)$ \\
\hline Observations & 6436 & 6436 & 6436 & 6436 & 6436 & 6436 \\
\hline $\mathrm{R}^{2}$ & 0.115 & 0.116 & 0.120 & 0.121 & 0.119 & 0.116 \\
\hline Set of control variables & Yes & Yes & Yes & Yes & Yes & Yes \\
\hline Weekday controls & No & No & No & No & No & No \\
\hline Day of the year variable & No & No & No & No & No & No \\
\hline \multicolumn{7}{|l|}{ B) } \\
\hline Euro-crisis intensity & 0.047 & $0.068^{* * *}$ & $0.091^{* * *}$ & $0.085^{* * *}$ & $0.069^{* *}$ & $0.058^{*}$ \\
\hline (trend adjusted) & $(0.030)$ & $(0.026)$ & $(0.024)$ & $(0.028)$ & $(0.033)$ & $(0.035)$ \\
\hline Observations & 6436 & 6436 & 6436 & 6436 & 6436 & 6436 \\
\hline $\mathrm{R}^{2}$ & 0.121 & 0.123 & 0.125 & 0.124 & 0.123 & 0.122 \\
\hline Set of control variables & Yes & Yes & Yes & Yes & Yes & Yes \\
\hline Weekday controls & Yes & Yes & Yes & Yes & Yes & Yes \\
\hline Day of the year variable & No & No & No & No & No & No \\
\hline \multicolumn{7}{|l|}{ C) } \\
\hline Euro-crisis intensity & $0.072^{*}$ & $0.102^{* * *}$ & $0.138^{* * *}$ & $0.126^{* * *}$ & $0.096^{* *}$ & $0.082^{* *}$ \\
\hline (trend adjusted) & $(0.037)$ & $(0.031)$ & $(0.030)$ & $(0.030)$ & $(0.038)$ & $(0.042)$ \\
\hline Observations & 6436 & 6436 & 6436 & 6436 & 6436 & 6436 \\
\hline $\mathrm{R}^{2}$ & 0.122 & 0.124 & 0.127 & 0.125 & 0.124 & 0.123 \\
\hline Set of control variables & Yes & Yes & Yes & Yes & Yes & Yes \\
\hline Weekday controls & Yes & Yes & Yes & Yes & Yes & Yes \\
\hline Day of the year variable & Yes & Yes & Yes & Yes & Yes & Yes \\
\hline
\end{tabular}

Notes: all specifications examine the probability of being very concerned about the euro dependent on the number of media reports on the euro crisis at the survey day (Specification 1) or earlier. Specifications $2 / 3 / 4 / 5 / 6$ use the lagged number from one day/two days/three days/four days/five days prior to the survey day. The set of control variables is the same as in Table 1. Standard errors are clustered on the interview date. Survey weights are used. All analyses in this table use data collected via self-completed questionnaires. SOEP data from 2011 and LexisNexis data are used.

* $p<.10$.

** $p<.05$.

*** $p<.01$.

away of the news effect and are thus established based on report number from the previous four days respectively previous three days.

While its validity is not directly testable, an IV can be checked regarding its effects in placebo outcomes that should not be responsive when the exogeneity argument is credible. To this aim, Table 3 presents first-stage results using IV 1 as the first version of the instrument. The data sample is again the data obtained in the private survey modes, and the outcomes are eight different types of concerns. The results are impressive as in seven cases the instrument is insignificant. The only concern affected throughout this analysis is the variable of interest, i.e., the concerns about the euro. Remarkably, the finding is the same when the IV is established on data from shorter time windows using IV2 and IV3 (see Appendix Tables A.2 and A.3). These results not only document a clean instrumental variation, they also underline the interpretation according to which it is not solely an economic effect at play when people are concerned about the euro. If this were the case, one might expect a link between euro crisis intensity and reported concerns about economic security, but the relationship is as insignificant as it is for all those concerns not related to the euro. ${ }^{19}$ Finally, the quantitative impact of the crisis on people's concerns can be assessed in an exemplary manner. Everything else held constant, a standard deviation increase of crisis coverage in the news (using IV1) goes along with a 5\% increase in the probability of reported concerns about the euro. Given that on average $20 \%$ of respondents report being very worried, this increase is substantial and allows for a relevant instrument.

\subsection{Second stage and sensitivity analyses}

Table 4 shows the main results from applying the IV approach in columns (2) to (4). The effect of euro concerns in reported life satisfaction turns out to be significantly negative and is robust to the consideration of differently defined instruments. The

\footnotetext{
19 Another placebo check applies the 2011 euro crisis indicator on the data from 2003 . Concerns about the euro on a given day in the year of 2003 are unrelated to the 2011 crisis news from the same date eight years later.
} 
Table 3

Various types of concerns and aggregated media coverage of the euro crisis (IV1).

\begin{tabular}{|c|c|c|c|c|}
\hline Specification: & (1) & (2) & (3) & (4) \\
\hline Concerns about: & Euro & General economic & Environment & Peace \\
\hline IV1: Euro-crisis intensity & $0.208^{* *}$ & 0.020 & -0.072 & -0.028 \\
\hline (aggregated over 7 days) & $(0.043)$ & $(0.043)$ & $(0.044)$ & $(0.053)$ \\
\hline Observations & 6436 & 6436 & 6436 & 6436 \\
\hline $\mathrm{R}^{2}$ & 0.128 & 0.059 & 0.032 & 0.051 \\
\hline Set of control variables & Yes & Yes & Yes & Yes \\
\hline Specification: & (5) & (6) & (7) & $(8)$ \\
\hline Concerns about: & Crime & Immigration & Xenophobia & Own economic \\
\hline IV1: Euro-crisis intensity & -0.053 & -0.064 & -0.007 & -0.012 \\
\hline (aggregated over 7 days) & $(0.053)$ & $(0.051)$ & $(0.037)$ & $(0.042)$ \\
\hline Observations & 6436 & 6436 & 6436 & 6436 \\
\hline $\mathrm{R}^{2}$ & 0.106 & 0.103 & 0.061 & 0.132 \\
\hline Set of control variables & Yes & Yes & Yes & Yes \\
\hline
\end{tabular}

Notes: all specifications examine the probability of being very concerned about a given topic, which is in the title of each column. The independent variable is always the aggregated number of media reports about the euro crisis. Aggregation implies summing up the media report numbers of the survey day plus those of the last six days. The set of control variables is the same as in Table 1 with an additional day of the year variable plus six weekday controls. Standard errors are clustered on the interview date. Survey weights are used. All analyses in this table use data collected via self-completed questionnaires. SOEP data from 2011 and LexisNexis data are used.

*** $p<.01$.

effect size is considerably strong and larger than the one derived from a comparable OLS regression without instrumentation, as shown in column (1). Also in comparison to other effects on people's well-being typically found in happiness research, the impact of being very concerned about the euro currency appears noticeably. The complete set of results for the second stage in Appendix Table C. 1 shows that the effect size is smaller but comparable to an event like the death of the partner.

Appendix Table A.4 presents results when the same approach is applied on a smaller sample. Arguably, the safest data with respect to potential social-desirability issues is from self-completed questionnaires that are filled out without any interviewer presence. Dropping the mixed mode data, however, does not change any of the findings. Another variation of the data sample and further sensitivity check of the IV approach re-examines the decision to focus on data from the months up to and including August, which is reasonable as there are fewer observations obtained the longer the year is, but there is increasing noise in the number of media reports. These additional results do not show anything new, demonstrating the robustness of the main effect found in people's well-being. Finally, the Big Five factors are in the center of the first empirical identification strategy, but it is

Table 4

Life satisfaction and concerns about the euro: instrumental variable analysis.

\begin{tabular}{|c|c|c|c|c|}
\hline Establishment of instrument & $(O L S)$ & IV1 & IV2 & IV3 \\
\hline Aggregation of media reports includes: & & Last six days & Last four days & Last three days \\
\hline First stage & & (1) & (2) & (3) \\
\hline \multirow{2}{*}{\multicolumn{2}{|c|}{ Euro-crisis intensity }} & $0.208^{* * *}$ & $0.184^{* * *}$ & $0.173^{* *}$ \\
\hline & & $(0.043)$ & $(0.037)$ & $(0.037)$ \\
\hline Observations & & 6436 & 6436 & 6436 \\
\hline $\mathrm{R}^{2}$ & & 0.128 & 0.127 & 0.127 \\
\hline Second stage & (0) & (1) & (2) & (3) \\
\hline Concerns about the euro & $\begin{array}{l}-0.457^{* * *} \\
(0.107)\end{array}$ & $\begin{array}{l}-1.642^{* *} \\
(0.782)\end{array}$ & $\begin{array}{l}-1.719^{* *} \\
(0.748)\end{array}$ & $\begin{array}{l}-1.756^{* 8} \\
(0.773)\end{array}$ \\
\hline Observations & 6436 & 6436 & 6436 & 6436 \\
\hline $\mathrm{R}^{2}$ & 0.206 & 0.142 & 0.133 & 0.129 \\
\hline Kleibergen-Paap Wald F statistic & & 23.870 & 24.473 & 22.107 \\
\hline Set of control variables & Yes & Yes & Yes & Yes \\
\hline
\end{tabular}

Notes: dependent variable in the second stage is life satisfaction on a 0 to 10 scale. Endogenous variable of being very concerned about the euro is the dependent variable in the first stage. The instrumental variable is the aggregated number of media reports about the euro crisis. Aggregation implies summing up the media report numbers of the survey day plus those of the last six/four/three days. The set of control variables is the same as in Table 1 with an additional day of the year variable plus six weekday controls. Standard errors are clustered on the interview date. Survey weights are used. All analyses in this table use data collected via self-completed questionnaires. SOEP data from 2011 and LexisNexis data are used.

** $p<.05$.

*** $p<.01$. 
possible to also control for personality differences using this measure in the IV analysis here. Adding the Big Five indicators does not change the findings and confirms the significantly negative effect of being concerned about the euro on the level of life satisfaction, as shown in Appendix Table A.5.

Another point worthy of discussion is a potential selection effect of certain types of individuals who choose a certain way of participating in the survey. Here, it is arguably more hypothetical to expect that people purposefully select themselves into certain survey dates or into private interview modes due to their views on the currency. It is possible however, that generally more pessimistic and unhappy individuals meet the criteria from the perspective of the interviewer to be offered an alternative to the face-to-face interview. Arguably, if there is such a selection of unhappy individuals, then it is all the more impressive to find effects when restricting the data to the private interview mode only, as the comparison takes place between systematically unhappier people, insofar as this selection argument holds. ${ }^{20}$ Instead, the impression from studying the data is that all participants have been treated by the exogenous variation in the political development, but a consistent reporting of both unhappiness and euro concerns has only taken place in the private interview mode.

\section{Discussion}

\subsection{Interpretation of results}

In interpreting the results, it is worthwhile to examine those people who are identified as concerned and unhappy individuals. which, for the IV results, refers to the methodological debate on the local average treatment effects and the compliers as the target group of an instrument (Imbens and Angrist, 1994; Angrist and Pischke, 2008). There are different types of people with concerns about the euro and its development, as also discussed in previous work on people's views about this currency (Isengard and Schneider, 2007). Someone who has always been rather skeptical of the euro currency does not need a crisis event to become concerned. Such a person is possibly not even identified in a longitudinal analysis, which identifies those who have changed their views. The existence of people who always have been concerned, of those who became concerned in the years after the euro implementation, and of others who became concerned during the crisis suggests applying an empirical strategy that considers multiple methodological approaches. While all three applied here come to the same conclusion, it is still important to understand who is susceptible to such treatment in the form of a developing euro crisis and the coverage about it, as those are the ones identified in the IV analysis. ${ }^{21}$ It is not the person with long-term beliefs regarding the euro currency who responds to such an instrument but instead it is the compliers, who show rather short-term reactions to recent news events. The finding of a significantly negative effect in those people's life satisfaction and the interpretation of a change in political attitudes requires some illustration.

At first, it is possible that the unhappy people identified in the IV analysis recover from their unhappiness and their potential frustration about the situation may decline with time. If there is such a momentary frustration at play that actually reduces people's reported happiness for only a limited time, this reduces the weight that one should give to the social costs aspect in interpreting the results. Yet, the experience of unhappiness and great anger can be enough to influence political views of some individuals. Whereas attitudes are generally known to be rather stable, the setting here is not necessarily in line with that when discussing the potential support for a party that is just about to come into existence. In a world with both perfectly stable political preferences and stable positions of existing parties, a protest party like the AfD cannot arise. At one point in time, some people must have changed their views and have come to the conclusion that there is a need for a new political representation. It could be that this moment of political re-orientation might have happened for some citizens in the investigation period analyzed here, even if their state of unhappiness was not necessarily long lasting.

The fact that the IV effects are confined to just one segment of the German population does not necessarily make the findings less telling or less important. If the study has found a small minority of Germans who were indeed affected in their well-being from being concerned about the euro, this fits well to the notion that it was also a minority who became politically involved to start the first major anti-euro protest movement in Germany. Probably less important is another restriction that goes along with using a media-based instrument, as compliers can only be consumers of media. However, the group of non-consumers is rather small in Germany and may not respond to political developments anyway.

Another issue with respect to the use of instrumental variables is that empirical researchers of non-experimental data can hardly be sure about the exact pathway of the observed effect. Moreover, a potential transmission channel can independently affect the outcome variable. Given a strong correlation with the variable of interest, the IV analysis would suggest a causal effect for the instrumented variable, while it rather serves as a proxy for the true factor. Outside of the laboratory, it is extremely hard to clarify the exact pathways, but it is possible here to at least make some statements over what the concerns about the euro (and the unhappiness connected to it) do not stand for. As mentioned above, people with concerns might have economic worries and

\footnotetext{
${ }^{20}$ Note that there is no empirical indication for strong selection phenomena into either mode or dates. For instance, separately conducted Heckman selection analyses yield no significant outcomes for potential selectivity in survey modes. As an example of how to check potential selectivity in survey dates, (lagged) crisis intensity can be used as a determinant for the frequency of completed questionnaires. No evidence for a crisis-induced postponing of survey participation emerges in this analysis. 21 To illustrate proportions, somewhat less than $20 \%$ of people on average report being very concerned about the euro. Compared to 2003 , half of the concerned people in 2011 had already reported strong concerns eight years earlier, while the other half had obviously changed their view. Out of the individuals in the 2011 sample used for the IV analysis, several hundreds and slightly more than $10 \%$ of observations were both worried about the euro and experienced above-trend crisis coverage in the news.
} 
Table 5

Concerns about the euro, life satisfaction and voting results: regional comparison.

\begin{tabular}{|c|c|c|c|}
\hline Specification: & (1) & (2) & (3) \\
\hline Regional share of people concerned about the euro & $\begin{array}{l}-0.012 \\
(0.008)\end{array}$ & $\begin{array}{l}-0.023^{* 7 *} \\
(0.007)\end{array}$ & $\begin{array}{l}-0.025^{20 * 7} \\
(0.007)\end{array}$ \\
\hline Regional average in life satisfaction among people & & $-0.003^{* *}$ & $-0.003^{* *}$ \\
\hline concerned about the euro & & $(0.001)$ & $(0.001)$ \\
\hline Regional average in life satisfaction & & $\begin{array}{l}-0.004^{*} \\
(0.002)\end{array}$ & $\begin{array}{l}-0.004 \\
(0.002)\end{array}$ \\
\hline Regional GDP & & & $\begin{array}{l}-0.003^{*} \\
(0.002)\end{array}$ \\
\hline Regional unemployment rate & & & $\begin{array}{l}0.023 \\
(0.032)\end{array}$ \\
\hline Regional share of foreigners & & & $\begin{array}{l}0.043 \\
(0.028)\end{array}$ \\
\hline Constant & $\begin{array}{l}0.033^{* *} \\
(0.001)\end{array}$ & $\begin{array}{l}0.033^{* * *} \\
(0.001)\end{array}$ & $\begin{array}{l}0.036^{* t+4} \\
(0.004)\end{array}$ \\
\hline Observations & 96 & 96 & 96 \\
\hline $\mathrm{R}^{2}$ & 0.016 & 0.147 & 0.184 \\
\hline
\end{tabular}

Notes: Dependent variable is the regional vote share for the AfD in the 2013 German federal elections. The first independent variable in Specifications ( 1 ) - (3) is the regional (demeaned) percentage of individuals reporting to be very concerned about the euro currency according to the SOEP data of 2011. The main independent variable in Specifications (2) - (3) is the regional (demeaned) average of reported life satisfaction among those individuals reporting to be very concerned about the euro currency according to the data of 2011. Included in Specifications (2) - (3) is the regional (demeaned) average of reported life satisfaction according to the SOEP data of 2011. Robust standard errors are in parentheses. Voting results for each regional policy region are based on own calculations using the 2013 federal election data from the federal election administration. Further independent variables at the regional level are the gross domestic product (in 10000 Euro per capita), the local unemployment rate and the share of foreigners in 2011. This data comes from the Federal Institute for Research on Building, Urban Affairs and Spatial Development.

* $p<.10$.

$* p<.05$

${ }^{* * *} p<.01$.

suffer from uncertainties. However, controlling for perceived security with respect to the state of the economy or with respect to one's own situation does not change the finding. In addition to the economic concern variables, an alternative outcome measure of people's expected life satisfaction in five years might yield evidence for a fear-of-the-economic development argument. If becoming aware of existing problems particularly affects people's expectations regarding their future, less so their current situation and the evaluation of it, they may appreciate the current situation of high living standards even more. However the results using expected life satisfaction as an outcome are very similar compared to those using the general life satisfaction variable. ${ }^{22}$ Finally, it is possible to exploit data on risk aversion in order to check the role of uncertainty. First, controlling for risk aversion does not change the findings in the IV analysis. Secondly, and more importantly, risk-averse people can be excluded from the analysis to see whether these individuals are the ones experiencing the decline in well-being from concerns about the euro. The findings are robust to such sample restriction, which further emphasizes the need for a different interpretation of the main effect than economic uncertainty. The final analysis takes a closer look at the potential role of political dissatisfaction.

\subsection{Unhappiness and election outcomes}

Previous studies discussing the link between politics and happiness mostly concentrate on the implications of political outcomes for people's well-being (e.g., Di Tella and MacCulloch, 2005; Tsutsui et al., 2010). The idea here is to follow recent research on the reverse relationship (Liberini et al., 2014; Ward, 2015) by postulating that the unhappier the people concerned about a political issue are, the more likely they are to change political views and become politically active. In order to incorporate the actual voting outcomes of the official 2013 German federal elections as a measure for the potential effect of the protest potential lying in the unhappiness of dissatisfied voters, this final analysis takes place at a regional level. This allows merging voting data with individual data from the SOEP, though the latter is used in aggregated form. Note that this analysis is not compatible with the IV analysis, as individuals with deep-rooted worries and long-term differences in attitudes are also considered; but it illustrates in an intuitive way the potential consequences of the euro-related unhappiness identified earlier.

The first variable of interest is the regional share of people reporting to be very concerned about the euro currency in 2011 . This allows testing whether the simple prevalence of more or less concerns about this specific topic predicts election outcomes. For each of the 96 ROR, a second indicator is established, introducing happiness data to this analysis. As the main variable of interest, it reflects the regional average in life satisfaction among those reporting to be very concerned about the euro. The argument here is that to identify the roots of political protest and subsequent political consequences, it is not enough to only look at people's concerns but to combine this with information on their (un)happiness, assuming that some individuals actually are

\footnotetext{
22 While this variable is only seldom used as an outcome variable in research (see, e.g., Frijters et al., 2009), it is available in both the 2003 and the 2011 SOEP wave. This is also the case for another variable, which in contrast appears useful for placebo checks: Replacing life satisfaction with dwelling satisfaction as alternative dependent variable shows no significant effects of being concerned about the euro in any of the performed analyses.
} 
unhappy because of their negative perceptions of the situation with their currency. The two variables are then linked to the AfD election results, specifically to the absolute number of the party's votes divided by the total number of eligible voters per region. ${ }^{23}$

Table 5 presents the evidence on the link between the regional voting outcome for the AfD in 2013 and the overall life satisfaction of the people who are concerned about the euro in 2011. The first variable of interest, the regional share of concerned people does not predict voting outcomes, as shown in column (1). This suggests that if people simply say that there is a topic of concern to them that this has no political implications necessarily. If however concerned individuals are increasingly unhappy with their lives in general, the results suggest a greater chance for political consequences. The significant effect in the second row confirms that lower happiness of worried individuals predicts greater electoral success for the anti-euro protest party. ${ }^{24}$ As shown in column (3), this finding holds when regional control variables are added and also when the overall level of life satisfaction per region is taken into account. ${ }^{25}$

To illustrate the intuition behind the figures, the two regions of Muenster in North Rhine-Westphalia and North Black Forest (Nordschwarzwald) in Baden-Wuerttemberg serve as examples. In the latter ROR (807), people with strong concerns about the euro report being much less satisfied with their lives in comparison to both the national average and the average of the other people living there. In addition to the strong election results that the $A f D$ received in many eastern regions of Germany, the $A f D$ received their best result of all the western regions in that ROR. Contrariwise, those who reported being very concerned about the euro currency in the ROR (511) of Muenster reported high levels of happiness in comparison and absolutely. Two years later, the $A f D$ received a rather minor election outcome there.

\section{Conclusion}

This study into the non-monetary implications of people's concerns about the euro currency provides both economically and politically relevant findings. First and foremost, the evidence in the SOEP data supports the hypothesis that people in Germany actually suffer from their concerns about the euro currency, measurable in reduced life satisfaction. This finding is universal to the use of several methodological approaches. The effect of being concerned about the euro does not lose its significance when economic insecurity is controlled for. Instead, the findings point to a political interpretation. Accordingly, euro-skeptic people are reporting both concerns and also lower happiness, which can be explained by the political situation in which frustrated citizens perceived a lack of representation in German party politics.

Knowing about the social desirability issue of having anti-euro views or being generally more in favor of nationalistic ideas, this study gives great attention to survey-specific aspects in the data collection process. Incorporating the discussion of survey methodology into the analysis demonstrates the important role that aspects, like the interview mode, are able to play in studies using subjective data. Assuming that it is possible to distinguish between more honest and less honest responses on the basis of survey modes, research can actually be enhanced by having information of such a technical kind.

The paper demonstrates how exogenous variation in the form of a developing euro crisis can be used as the basis for an IV analysis. To identify the effect of being concerned about the currency, the study combines data on the quantity of media reports with technical information on the interview dates to identify survey participants that are exogenously affected by the varying intensity of the crisis. The determination of an interview date may have its influencing factors, but the anticipation of a political event with reference to the euro currency is not plausibly among those. The instrument fulfills the criterion of relevance, as concerns about the euro increase strongly when the crisis indicator does so beforehand, and it also appears to be valid, as no other concerns of the people are affected.

With respect to the economic implications, any significant reduction in people's life satisfaction is of concern from a social perspective. Beyond the economic relevance of unhappiness itself, there is also a political relevance of this type of subjectively perceived discomfort. Some people may have been very dissatisfied because of their concerns about the economic issue of the currency and the perception that those views were not fully represented in politics. Following this line of argument, the paper gives an illustration of how protest movements can start and how subjective data can contribute to the understanding of people's behavior.

The link between individual unhappiness and political activity appears to be a very promising topic for future research. During the finalization of this paper, the AfD became an established power in the political spectrum of Germany, entering one parliament after another. Similar parties have gathered election successes across Europe. The effects revealed in the study may reflect one of the origins of this type of protest and the formation of another anti-euro party having its foundation in the unhappiness of an angry minority of citizens who appeared to be very concerned about their currency in times of overall happiness and economic abundance.

\footnotetext{
${ }^{23}$ An alternative is to use the total number of valid votes per region as a reference, which is done by the election officials to determine the election results and thus also in the illustrative examples in Section 2. However, according to this official definition, a party's success depends on the success of the other parties, which makes the use of the other definition superior when analyzing solely the success of a specific party. Note that the results in Table 5 are not sensitive to this decision of how to define the voting share.

24 This relationship also exists when this additional analysis is conducted on the basis of the smaller data set from self-completed questionnaires without an interviewer presence, despite the loss of data. Note that only the full data set allows consideration of all the 96 ROR due to sufficient observation numbers.

${ }_{25}$ This descriptive finding also remains robust to a more complex determination of the regional unhappiness among euro-concerned individuals. To this aim, the happiness averages can be replaced with interaction coefficients from separate regressions based on model (1), which additionally include variables for all regions and their interactions with the indicator of being strongly concerned about the euro. This exercise allows taking differences in the Big Five personality measures as well as all the other available control variables into account
} 


\section{Acknowledgments}

I am grateful to the editor, Jan-Egbert Sturm, and two anonymous referees who helped to improve the paper. Furthermore, I would like to thank Sam Butterick, Manuel Hoffmann, Matthias Krapf, Hildegunn Stokke, the participants of the 2015 European Public Choice Society conference as well as the seminar participants in Trier for comments and suggestions. Marina Dormels and Ramona Heeke provided excellent research assistance.

\section{Appendix A. Additional tables}

Table A.1

Concerns about the euro and media coverage of the euro crisis (oral interview data).

\begin{tabular}{|c|c|c|c|c|c|c|}
\hline Specification: & (1) & (2) & (3) & (4) & (5) & (6) \\
\hline Lag: & none & 1 day & 2 days & 3 days & 4 days & 5 days \\
\hline \multicolumn{7}{|l|}{ A) } \\
\hline Euro-crisis intensity & 0.024 & 0.030 & $0.055^{*}$ & $0.052^{*}$ & $0.050^{* *}$ & 0.003 \\
\hline (trend adjusted) & $(0.027)$ & $(0.028)$ & $(0.028)$ & $(0.029)$ & $(0.025)$ & $(0.027)$ \\
\hline Observations & 6082 & 6082 & 6082 & 6082 & 6082 & 6082 \\
\hline $\mathrm{R}^{2}$ & 0.072 & 0.072 & 0.073 & 0.073 & 0.073 & 0.071 \\
\hline Set of control variables & Yes & Yes & Yes & Yes & Yes & Yes \\
\hline Weekday controls & No & No & No & No & No & No \\
\hline Day of the year variable & No & No & No & No & No & No \\
\hline \multicolumn{7}{|l|}{ B) } \\
\hline Euro-crisis intensity & 0.033 & $0.049^{*}$ & $0.064^{* *}$ & 0.044 & $0.058^{* *}$ & 0.008 \\
\hline (trend adjusted) & $(0.027)$ & $(0.027)$ & $(0.032)$ & $(0.033)$ & $(0.029)$ & $(0.028)$ \\
\hline Observations & 6436 & 6436 & 6436 & 6436 & 6436 & 6436 \\
\hline $\mathrm{R}^{2}$ & 0.075 & 0.075 & 0.076 & 0.075 & 0.076 & 0.074 \\
\hline Set of control variables & Yes & Yes & Yes & Yes & Yes & Yes \\
\hline Weekday controls & Yes & Yes & Yes & Yes & Yes & Yes \\
\hline Day of the year variable & No & No & No & No & No & No \\
\hline \multicolumn{7}{|l|}{ C) } \\
\hline Euro-crisis intensity & 0.029 & $0.051^{*}$ & $0.071^{*}$ & 0.042 & $0.059^{*}$ & -0.007 \\
\hline (trend adjusted) & $(0.031)$ & $(0.030)$ & $(0.037)$ & $(0.038)$ & $(0.032)$ & $(0.030)$ \\
\hline Observations & 6436 & 6436 & 6436 & 6436 & 6436 & 6436 \\
\hline $\mathrm{R}^{2}$ & 0.075 & 0.075 & 0.076 & 0.075 & 0.076 & 0.075 \\
\hline Set of control variables & Yes & Yes & Yes & Yes & Yes & Yes \\
\hline Weekday controls & Yes & Yes & Yes & Yes & Yes & Yes \\
\hline Day of the year variable & Yes & Yes & Yes & Yes & Yes & Yes \\
\hline
\end{tabular}

Notes: all specifications examine the probability of being very concerned about the euro dependent on the number of media reports on the euro crisis at the survey day (Specification 1) or earlier. Specifications 2/3/4/5/6 use the lagged number from one day/two days/three days/four days/five days prior to the survey day. The set of control variables is the same as in Table 1. Standard errors are clustered on the interview date. Survey weights are used. All analyses in this table use data collected via oral interviews. SOEP data from 2011 and LexisNexis data are used.

$p<.10$.

$* p<.05$.

Table A.2

Various types of concerns and aggregated media coverage of the euro crisis (IV2).

\begin{tabular}{|c|c|c|c|c|}
\hline Specification: & (1) & (2) & (3) & (4) \\
\hline Concerns about: & Euro & General economic & Environment & Peace \\
\hline $\begin{array}{l}\text { IV1: Euro-crisis intensity } \\
\text { (aggregated over } 7 \text { days) }\end{array}$ & $\begin{array}{l}0.184^{* * *} \\
(0.037)\end{array}$ & $\begin{array}{l}0.009 \\
(0.037)\end{array}$ & $\begin{array}{l}-0.053 \\
(0.041)\end{array}$ & $\begin{array}{l}-0.039 \\
(0.049)\end{array}$ \\
\hline Observations & 6436 & 6436 & 6436 & 6436 \\
\hline $\mathrm{R}^{2}$ & 0.127 & 0.059 & 0.032 & 0.051 \\
\hline Set of control variables & Yes & Yes & Yes & Yes \\
\hline Specification: & (5) & (6) & (7) & (8) \\
\hline Concerns about: & Crime & Immigration & Xenophobia & Own economic \\
\hline $\begin{array}{l}\text { IVI: Euro-crisis intensity } \\
\text { (aggregated over } 7 \text { days) }\end{array}$ & $\begin{array}{l}-0.058 \\
(0.048)\end{array}$ & $\begin{array}{l}-0.042 \\
(0.045)\end{array}$ & $\begin{array}{l}-0.013 \\
(0.034)\end{array}$ & $\begin{array}{l}-0.009 \\
(0.037)\end{array}$ \\
\hline Observations & 6436 & 6436 & 6436 & 6436 \\
\hline
\end{tabular}


Table A.2 (continued)

\begin{tabular}{|c|c|c|c|c|}
\hline Specification: & (5) & (6) & (7) & (8) \\
\hline Concerns about: & Crime & Immigration & Xenophobia & Own economic \\
\hline $\mathrm{R}^{2}$ & 0.106 & 0.103 & 0.061 & 0.132 \\
\hline Set of control variables & Yes & Yes & Yes & Yes \\
\hline
\end{tabular}

Notes: all specifications examine the probability of being very concerned about a given topic, which is in the title of each column. The independent variable is always the aggregated number of media reports about the euro crisis. Aggregation implies summing up the media report numbers of the survey day plus those of the last four days. The set of control variables is the same as in Table 1 with an additional day of the year variable plus six weekday controls. Standard errors are clustered on the interview date. Survey weights are used. All analyses in this table use data collected via self-completed questionnaires. SOEP data from 2011 and LexisNexis data are used.

*** $p<.01$.

Table A.3

Various types of concerns and aggregated media coverage of the euro crisis (IV3).

\begin{tabular}{|c|c|c|c|c|}
\hline Specification: & (1) & (2) & (3) & (4) \\
\hline Concerns about: & Euro & General economic & Environment & Peace \\
\hline IV1: Euro-crisis intensity & $0.173^{* * *}$ & -0.004 & -0.048 & -0.036 \\
\hline (aggregated over 7 days) & $(0.037)$ & $(0.037)$ & $(0.040)$ & $(0.047)$ \\
\hline Observations & 6436 & 6436 & 6436 & 6436 \\
\hline $\mathrm{R}^{2}$ & 0.127 & 0.059 & 0.032 & 0.051 \\
\hline Set of control variables & Yes & Yes & Yes & Yes \\
\hline Specification: & (5) & (6) & (7) & (8) \\
\hline Concerns about: & Crime & Immigration & Xenophobia & Own economic \\
\hline IV1: Euro-crisis intensity & -0.063 & -0.029 & -0.018 & -0.010 \\
\hline (aggregated over 7 days) & $(0.045)$ & $(0.042)$ & $(0.033)$ & $(0.036)$ \\
\hline Observations & 6436 & 6436 & 6436 & 6436 \\
\hline $\mathrm{R}^{2}$ & 0.106 & 0.103 & 0.061 & 0.132 \\
\hline Set of control variables & Yes & Yes & Yes & Yes \\
\hline
\end{tabular}

Notes: all specifications examine the probability of being very concerned about a given topic, which is in the title of each column. The independent variable is always the aggregated number of media reports about the euro crisis. Aggregation implies summing up the media report numbers of the survey day plus those of the last three days. The set of control variables is the same as in Table 1 with an additional day of the year variable plus six weekday controls. Standard errors are clustered on the interview date. Survey weights are used. All analyses in this table use data collected via self-completed questionnaires. SOEP data from 2011 and LexisNexis data are used.

*** $p<, 01$.

Table A.4

Life satisfaction and concerns about the euro: IV analysis (smaller data sample).

\begin{tabular}{|c|c|c|c|c|}
\hline Establishment of instrument & $(O L S)$ & $I V 1$ & IV2 & IV3 \\
\hline Aggregation of media reports includes: & & Last six days & Last four days & Last three days \\
\hline First stage & & (1) & (2) & (3) \\
\hline Euro-crisis intensity & & $\begin{array}{l}0.233^{* * *} \\
(0.046)\end{array}$ & $\begin{array}{l}0.208^{* * *} \\
(0.040)\end{array}$ & $\begin{array}{l}0.190^{* * *} \\
(0.040)\end{array}$ \\
\hline Observations & & 5570 & 5570 & 5570 \\
\hline $\mathrm{R}^{2}$ & & 0.139 & 0.139 & 0.138 \\
\hline Second stage & $(0)$ & (1) & $(2)$ & (3) \\
\hline Concerns about the euro & $\begin{array}{l}-0.467^{* * *} \\
(0.117)\end{array}$ & $\begin{array}{l}-1.590^{* *} \\
(0.775)\end{array}$ & $\begin{array}{l}-1.808^{* *} \\
(0.745)\end{array}$ & $\begin{array}{l}-1.923^{* *} \\
(0.796)\end{array}$ \\
\hline Observations & 5570 & 5570 & 5570 & 5570 \\
\hline $\mathrm{R}^{2}$ & 0.204 & 0.148 & 0.123 & 0.109 \\
\hline Kleibergen-Paap Wald F statistic & & 25.641 & 27.505 & 22.615 \\
\hline Set of control variables & Yes & Yes & Yes & Yes \\
\hline
\end{tabular}

Notes: dependent variable in the second stage is life satisfaction on a 0 to 10 scale. Endogenous variable of being very concerned about the euro is the dependent variable in the first stage. The instrumental variable is the aggregated number of media reports about the euro crisis. Aggregation implies summing up the media report numbers of the survey day plus those of the last six/four/three days. The set of control variables is the same as in Table 1 with an additional day of the year variable plus six weekday controls. Standard errors are clustered on the interview date. Survey weights are used. All analyses in this table use data collected via self-completed questionnaires without interviewer presence. SOEP data from 2011 and LexisNexis data are used.

** $p<.05$.

**) $p<.01$. 
Table A.5

Life satisfaction and concerns about the euro: IV analysis (Big Five personality included).

\begin{tabular}{|c|c|c|c|c|}
\hline Establishment of instrument & $(O L S)$ & IV1 & IV2 & IV3 \\
\hline Aggregation of media reports includes: & & Last six days & Last four days & Last three days \\
\hline First stage & & (1) & (2) & (3) \\
\hline Euro-crisis intensity & & $\begin{array}{l}0.195^{* * *} \\
(0.040)\end{array}$ & $\begin{array}{l}0.174^{* * *} \\
(0.035)\end{array}$ & $\begin{array}{l}0.165^{\circ * *} \\
(0.034)\end{array}$ \\
\hline Observations & & 6436 & 6436 & 6436 \\
\hline $\mathrm{R}^{2}$ & & 0.145 & 0.145 & 0.145 \\
\hline Second stage & (0) & (1) & (2) & (3) \\
\hline Concerns about the euro & $\begin{array}{l}-0.414^{* *} \\
(0.103)\end{array}$ & $\begin{array}{l}-1.609^{* *} \\
(0.775)\end{array}$ & $\begin{array}{l}-1.733^{* *} \\
(0.742)\end{array}$ & $\begin{array}{l}-1.817^{* *} \\
(0.768)\end{array}$ \\
\hline Observations & 6436 & 6436 & 6436 & 6436 \\
\hline $\mathrm{R}^{2}$ & 0.244 & 0.180 & 0.166 & 0.156 \\
\hline Kleibergen-Paap Wald F statistic & & 23.755 & 25.028 & 22.921 \\
\hline Set of control variables & Yes & Yes & Yes & Yes \\
\hline Big Five personality & Yes & Yes & Yes & Yes \\
\hline
\end{tabular}

Notes: dependent variable in the second stage is life satisfaction on a 0 to 10 scale. Endogenous variable of being very concerned about the euro is the dependent variable in the first stage. The instrumental variable is the aggregated number of media reports about the euro crisis. Aggregation implies summing up the media report numbers of the survey day plus those of the last six/four/three days. The set of control variables is the same as in Table 1 with an additional day of the year variable plus six weekday controls. See Table 1 for more information on Big Five personality factors. Standard errors are clustered on the interview date. Survey weights are used. All analyses in this table use data collected via self-completed questionnaires. SOEP data from 2011 (with Big Five measures from 2009 ) and LexisNexis data are used.

** $p<.05$.

$* * * 01$.

\section{Appendix B. Background information}

The two tables in Appendix B illustrate the situation in Germany during the year 2011 by means of media excerpts. The overview of the news headlines shows how the German people were faced with a euro crisis that so far had played hardly any role in their lives, economically speaking. It did, however, play a large role in the media that the German people were consuming, which is shown in Table B.1 that deals with the concerns about the euro. The list includes headlines and exemplary quotes from the most remarkable events of that year, such as the Portugal bailout.

In contrast to the more worrying media reports on the euro crisis, a very positive picture emerges when looking at the collection of media reports that Table B.2 presents. This positive view on the situation in Germany comes from the recognition that the economic turmoil only took place in other European countries, especially in the south, while the country with Europe's largest economy was actually doing very well in economic terms. This paradoxical phenomenon of extraordinary happiness in Germany during times of crisis is well demonstrated by a study on the well-being of Germans, which gained much attention in the media. The authors (Köcher and Raffelhüschen, 2011) came to the conclusion that happiness was so widespread in Germany, despite the ongoing euro crisis, that the national average of people's satisfaction with their lives had reached heights the country had not seen for many years.

Table B.1

The euro crisis in the German media.

\begin{tabular}{|c|c|c|}
\hline Date & Headline/Excerpt & Source \\
\hline $\begin{array}{l}\text { March } \\
12\end{array}$ & $\begin{array}{l}\text { Toeing the line with a new Euro-pact: an accord should provide more currency stability-the plan to do so remains vague. } \\
\text { "Government leaders from } 17 \text { countries are hoping to calm financial market turbulence with a new pact for the Euro. Insiders, } \\
\text { however, expressed concerns that the new agreement alone will not be sufficient. Risk surcharges for countries that remain on the } \\
\text { brink could, in fact, continue to rise. A high-ranking EU diplomat told Die Welt This new pact is an empty shell:" }\end{array}$ & Die Welt \\
\hline March & Is Portugal the next to need financial help? & Der Tagesspiegel \\
\hline 22 & $\begin{array}{l}\text { "For the first time since the beginning of the crisis, the Portuguese government is considering accepting assistance from the Euro } \\
\text { rescue fund." }\end{array}$ & \\
\hline March & Portuguese government collapses due to austerity measures. & Spiegel Online \\
\hline 23 & $\begin{array}{l}\text { "Portugal's govermment has failed: Prime Minister Socrates has announced his resignation - he was unable to gather a majority in } \\
\text { parliament to support his austerity measures. The country is now facing uncertain times." }\end{array}$ & \\
\hline March & Another rise in Euro anxiety: The resignation of Prime Minister Jose Socrates is causing a crisis in more than just Portugal. & Stuttgarter \\
\hline 24 & $\begin{array}{l}\text { "The little land of Portugal is frightening itself and the whole of Europe. Portugal is deeply indebted and the poorest of all western } \\
\text { European countries and now the Prime Minister has resigned. The fact that Jose Socrates chose to resign on, of all days, the day } \\
\text { before the EU summit in Brussels, is causing the much feared political MCA." }\end{array}$ & Nachrichten \\
\hline $\begin{array}{l}\text { March } \\
25\end{array}$ & $\begin{array}{l}\text { Portugal's government is done: The socialist minority administration of Jose Socrates has collapsed under the weight of the } \\
\text { austerity measures. }\end{array}$ & taz \\
\hline
\end{tabular}


Table B.1 (continued)

\begin{tabular}{|c|c|c|}
\hline Date & Headline/Excerpt & Source \\
\hline & $\begin{array}{l}\text { "It is assumed to be precluded that Portugal will apply for assistance during the two day EU summit which is now taking place. In } \\
\text { the intermediate-term, however, it will be difficult to avoid seeking aid from either the EU or the IMF." }\end{array}$ & \\
\hline April & Finance crisis: Portugal applies for Euro crisis aid. & Berliner Morgenpost \\
\hline 06 & $\begin{array}{l}\text { "An application for aid could only be seen as a last resort. Within the EU, the worry that neighboring Spain will be the next to slip } \\
\text { into the mess named the Euro-debt-crisis dominates." }\end{array}$ & Online \\
\hline April & Portugal's government requests billions in aid from the EU after all. & Hamburger \\
\hline 07 & "Portugal is, after Greece and Ireland, the third to fall into the European safety net." & Abendblatt \\
\hline $\begin{array}{l}\text { April } \\
08\end{array}$ & $\begin{array}{l}\text { Relief after Portugal's call for help: An aid package should be quickly adopted - and with a scope of in between } 60 \text { and } \\
80 \text { billion Euros. } \\
\text { "Portugal's fall into the safety net was applauded." }\end{array}$ & Börsen-Zeitung \\
\hline Mai & Bail-out package: Portugal's banks receive 12 billion Euros. & Berliner Morgenpost \\
\hline 04 & $\begin{array}{l}\text { "The deeply indebted country, with the help of the EU and the IMF, has agreed to a package containing } 78 \text { billion Euros. The citizens } \\
\text { will have to tighten their belts." }\end{array}$ & Online \\
\hline Mai & Portugal receives 78 billion from the EU and the IMF - for a promise of extreme austerity measures; despite the help, two & Hamburger \\
\hline \multirow[t]{2}{*}{05} & years of recession are looming. & Abendblatt \\
\hline & "Portugal's people will pay a high price for the EU aid package." & Online \\
\hline Mai & Schäuble promotes Portugal aid - the German Federal Parliament votes yes. & DAPD \\
\hline 12 & "The majority of the Bundestag voted yes on a non-binding resolution accepting the 78 billion Euro aid package for Portugal." & \\
\hline July & After Portugal, Italy comes under pressure. & Die Presse \\
\hline 07 & $\begin{array}{l}\text { "At the same time, worries over Italy's position grow. Due to its precarious financial balance, it could be the next country to come } \\
\text { under pressure." }\end{array}$ & \\
\hline July & Fear of Italian bankruptcy grows. & Rheinische Post \\
\hline 13 & $\begin{array}{l}\text { "The fear of an Italian bankruptcy grows. The situation in the EU's third largest economy is re-invoking bad memories from the } \\
\text { Lehman Brothers bankruptcy which started the financial crisis of 2008." }\end{array}$ & \\
\hline July & Dangerous fears about the Euro. & B.Z. \\
\hline 19 & "The people's worries about their money are not to be ignored." & \\
\hline
\end{tabular}

Table B2

Positive media reports of 2011 on the situation in Germany.

\begin{tabular}{|c|c|c|}
\hline Date & Headline/Excerpt & Source \\
\hline February & Germans more optimistic than ever. & Berliner \\
\hline 23 & $\begin{array}{l}\text { "The Germans are readier to buy than they've been for years. The good mood in the markets is increasingly animating normal } \\
\text { consumers," }\end{array}$ & Morgenpost \\
\hline March & Employment explosion: Excitement in the German job market. & Immobilien \\
\hline 03 & $\begin{array}{l}\text { "While the jobless numbers around the world rose, German numbers remained almost unchanged. [... I - as a result, foreign } \\
\text { markets today observe the German job miracle with interest." }\end{array}$ & Zeitung \\
\hline March & Economic growth: Germany's economists predict a marathon boom. & Welt Online \\
\hline 11 & $\begin{array}{l}\text { "The British paper 'Economist' titled a recent article about the German economic upturn "Angie in Wonderland". The British paper } \\
\text { maintained that Angela Merkel is living in an economic fairy tale land as Germany outpaces every single other European national } \\
\text { economy." }\end{array}$ & \\
\hline May & First class recovery: Economic growth better than before the crisis. & Kölnische \\
\hline 25 & $\begin{array}{l}\text { "The German economy maintains high spirits. Driven by strong investments, the robust upswing has increased pace in the first } \\
\text { quarter." }\end{array}$ & Rundschau \\
\hline August & The role model is called Germany. & Focus Magazin \\
\hline 13 & $\begin{array}{l}\text { "In analyses on economic renewal, experts return again and again to a familiar role model: Germany. "Look! In the sky! Is it a bird, is } \\
\text { it a plane? No! It's the German economy!" enthused renowned New Yorker economist Robert Brusca." }\end{array}$ & \\
\hline August & Some scream "Recession!" but Germany could walk away unscathed. & Die ZEIT \\
\hline 25 & "It helps Germany that it isn't the sickling anymore, instead it's Europe's muscle man." & \\
\hline $\begin{array}{l}\text { September } \\
01\end{array}$ & $\begin{array}{l}\text { Unemployment historically low: The status of the job market remained unchanged in August. Retailers are betting on good } \\
\text { sales. } \\
\text { "Germany has the fourth lowest unemployment rate in all of Europe; among the } 27 \text { EU-States, Germany is shining." }\end{array}$ & Welt Kompakt \\
\hline September & Study: What makes a happy German different. & Spiegel Online \\
\hline 20 & "Germans feel better today than they have since 2001 - despite the crisis." & \\
\hline September & Completely contented: During the crisis, the Germans remain optimistic. & Nürnberger \\
\hline 21 & $\begin{array}{l}\text { "Germans have retained their optimism that the financial and euro crisis cannot affect their positive attitude towards life. Quite the } \\
\text { opposite. in fact, the happiness factor has actually increased to a new record level." }\end{array}$ & Nachrichten \\
\hline September & According to a new study, the Germans are more satisfied than ever before. & Welt kompakt \\
\hline 21 & $\begin{array}{l}\text { "The Euro crisis and the danger of a possible recession fail to impress most people: measurements of subjective life satisfaction show } \\
\text { an upward trend. }\end{array}$ & \\
\hline $\begin{array}{l}\text { October } \\
25\end{array}$ & $\begin{array}{l}\text { Germans, despite the Euro crisis, remain in a buying mood: A strong labor market is maintaining a positive atmosphere. } \\
\text { "Despite Euro worries, /... / German citizens expect to contimue to earn well and are planning larger personal investments." }\end{array}$ & Welt aktuell \\
\hline $\begin{array}{l}\text { November } \\
25\end{array}$ & $\begin{array}{l}\text { Consumer elation is warming the business climate: In the third quarter, the German economy grew by } 0.5 \% \text {, outstripping } \\
\text { expectations. } \\
\text { "In the middle of the Euro debt crisis, the investment happy consumers and businesses have given the German economy another } \\
\text { shot in the arm." }\end{array}$ & $\begin{array}{l}\text { Hamburger } \\
\text { Abendblatt }\end{array}$ \\
\hline November & Strong German labor market despite European debt crisis. & AFP \\
\hline 30 & "German labour market has proved to be far more stable than rest of Europe." & \\
\hline
\end{tabular}


Table B.2 (continued)

\begin{tabular}{|c|c|c|}
\hline Date & Headline/Excerpt & Source \\
\hline December & Fall fairy tale for the labor market: Only 2.713 million jobless in Germany. & Welt kompakt \\
\hline 01 & "The sovereign debt crisis in Europe has not affect the German labour market." & \\
\hline $\begin{array}{l}\text { December } \\
30\end{array}$ & $\begin{array}{l}\text { The Germans are confident about 2012: Those who earn well, have little to fear in the new year, according to a turn of the year } \\
\text { poll. } \\
\text { "Despite all the crises, Germans are approaching the new year optimistically. } 49 \% \text { believe that } 2012 \text { will a good year for them." }\end{array}$ & $\begin{array}{l}\text { Generalanzeiger } \\
\text { Bonn }\end{array}$ \\
\hline
\end{tabular}

\section{Appendix C. Complete results}

Table C.1

Life satisfaction and concerns about the euro: complete results of the IV analysis (second stage).

\begin{tabular}{|c|c|c|c|c|}
\hline Method: & OLS & IV & IV & IV \\
\hline Specification: & (1) & (2) & (3) & (4) \\
\hline Female & $\begin{array}{l}0.019 \\
(0.062)\end{array}$ & $\begin{array}{l}-0.022 \\
(0.071)\end{array}$ & $\begin{array}{c}-0.025 \\
(0.070)\end{array}$ & $\begin{array}{c}-0.026 \\
(0.070)\end{array}$ \\
\hline Direct migration background & $\begin{array}{l}0.033 \\
(0.165)\end{array}$ & $\begin{array}{l}-0.065 \\
(0.181)\end{array}$ & $\begin{array}{l}-0.071 \\
(0.177)\end{array}$ & $\begin{array}{l}-0.074 \\
(0.178)\end{array}$ \\
\hline Indirect migration background & $\begin{array}{l}0.105 \\
(0.127)\end{array}$ & $\begin{array}{l}0.096 \\
(0.132)\end{array}$ & $\begin{array}{l}0.095 \\
(0.133)\end{array}$ & $\begin{array}{l}0.095 \\
(0.133)\end{array}$ \\
\hline Age & $\begin{array}{l}-0.060 \\
(0.063)\end{array}$ & $\begin{array}{l}-0.033 \\
(0.065)\end{array}$ & $\begin{array}{l}-0.031 \\
(0.066)\end{array}$ & $\begin{array}{l}-0.030 \\
(0.066)\end{array}$ \\
\hline Age squared & $\begin{array}{l}0.000 \\
(0.001)\end{array}$ & $\begin{array}{c}-0.000 \\
(0.001)\end{array}$ & $\begin{array}{l}-0.000 \\
(0.001)\end{array}$ & $\begin{array}{l}-0.000 \\
(0.001)\end{array}$ \\
\hline Age cubed & $\begin{array}{l}0.000 \\
(0.000)\end{array}$ & $\begin{array}{l}0.000 \\
(0.000)\end{array}$ & $\begin{array}{l}0.000 \\
(0.000)\end{array}$ & $\begin{array}{l}0.000 \\
(0.000)\end{array}$ \\
\hline German nationality & $\begin{array}{c}-0.024 \\
(0.224)\end{array}$ & $\begin{array}{l}0.004 \\
(0.230)\end{array}$ & $\begin{array}{l}0.006 \\
(0.231)\end{array}$ & $\begin{array}{l}0.007 \\
(0.232)\end{array}$ \\
\hline Turkish nationality & $\begin{array}{l}0.542 \\
(0.359)\end{array}$ & $\begin{array}{l}0.535 \\
(0.403)\end{array}$ & $\begin{array}{l}0.534 \\
(0.407)\end{array}$ & $\begin{array}{l}0.534 \\
(0.408)\end{array}$ \\
\hline Italian nationality & $\begin{array}{l}0.153 \\
(0.376)\end{array}$ & $\begin{array}{l}0.121 \\
(0.429)\end{array}$ & $\begin{array}{l}0.118 \\
(0.434)\end{array}$ & $\begin{array}{l}0.117 \\
(0.436)\end{array}$ \\
\hline Greek nationality & $\begin{array}{l}1.883^{* *} \\
(0.920)\end{array}$ & $\begin{array}{l}2.113^{\circ} \\
(1.106)\end{array}$ & $\begin{array}{l}2.128^{*} \\
(1.112)\end{array}$ & $\begin{array}{l}2.135^{\circ} \\
(1.122)\end{array}$ \\
\hline Catholic & $\begin{array}{l}0.172^{*} \\
(0.100)\end{array}$ & $\begin{array}{l}0.184^{\prime} \\
(0.100)\end{array}$ & $\begin{array}{l}0.185^{*} \\
(0.101)\end{array}$ & $\begin{array}{l}0.185^{*} \\
(0.101)\end{array}$ \\
\hline Protestant & $\begin{array}{l}0.048 \\
(0.103)\end{array}$ & $\begin{array}{l}0.093 \\
(0.108)\end{array}$ & $\begin{array}{l}0.095 \\
(0.109)\end{array}$ & $\begin{array}{l}0.097 \\
(0.110)\end{array}$ \\
\hline Other religion & $\begin{array}{l}-0.403^{*} \\
(0.235)\end{array}$ & $\begin{array}{l}-0.354 \\
(0.247)\end{array}$ & $\begin{array}{l}-0.351 \\
(0.247)\end{array}$ & $\begin{array}{l}-0.349 \\
(0.248)\end{array}$ \\
\hline Secondary education & $\begin{array}{l}0.034 \\
(0.123)\end{array}$ & $\begin{array}{l}0.068 \\
(0.119)\end{array}$ & $\begin{array}{l}0.070 \\
(0.117)\end{array}$ & $\begin{array}{l}0.071 \\
(0.116)\end{array}$ \\
\hline Tertiary education & $\begin{array}{l}0.346^{*} \\
(0.198)\end{array}$ & $\begin{array}{l}0.426^{* 1} \\
(0.189)\end{array}$ & $\begin{array}{l}0.431^{* 4} \\
(0.185)\end{array}$ & $\begin{array}{l}0.433^{* 6} \\
(0.183)\end{array}$ \\
\hline Education years & $\begin{array}{l}0.209 \\
(0.136)\end{array}$ & $\begin{array}{l}0.056 \\
(0.175)\end{array}$ & $\begin{array}{l}0.046 \\
(0.171)\end{array}$ & $\begin{array}{l}0.042 \\
(0.172)\end{array}$ \\
\hline Education years squared & $\begin{array}{l}-0.008^{*} \\
(0.005)\end{array}$ & $\begin{array}{l}-0.004 \\
(0.006)\end{array}$ & $\begin{array}{l}-0.004 \\
(0.006)\end{array}$ & $\begin{array}{l}-0.004 \\
(0.006)\end{array}$ \\
\hline Full-time employment & $\begin{array}{l}-0.211 \\
(0.223)\end{array}$ & $\begin{array}{l}-0.088 \\
(0.243)\end{array}$ & $\begin{array}{l}-0.080 \\
(0.242)\end{array}$ & $\begin{array}{l}-0.076 \\
(0.241)\end{array}$ \\
\hline Regular part-time employment & $\begin{array}{l}-0.017 \\
(0.204)\end{array}$ & $\begin{array}{l}0.105 \\
(0.219)\end{array}$ & $\begin{array}{l}0.113 \\
(0.217)\end{array}$ & $\begin{array}{l}0.116 \\
(0.216)\end{array}$ \\
\hline Marginal, irregular part-time employment & $\begin{array}{l}-0.201 \\
(0.264)\end{array}$ & $\begin{array}{l}-0.082 \\
(0.299)\end{array}$ & $\begin{array}{c}-0.074 \\
(0.300)\end{array}$ & $\begin{array}{l}-0.070 \\
(0.298)\end{array}$ \\
\hline Out of labor force & $\begin{array}{c}-0.014 \\
(0.227)\end{array}$ & $\begin{array}{l}0.089 \\
(0.248)\end{array}$ & $\begin{array}{l}0.096 \\
(0.245)\end{array}$ & $\begin{array}{l}0.099 \\
(0.243)\end{array}$ \\
\hline Registered as unemployed & $\begin{array}{l}-0.740^{* * *} \\
(0.181)\end{array}$ & $\begin{array}{l}-0.728^{* *+} \\
(0.180)\end{array}$ & $\begin{array}{l}-0.727^{* *} \\
(0.181)\end{array}$ & $\begin{array}{l}-0.726^{2 *} \\
(0.182)\end{array}$ \\
\hline Self-employed & $\begin{array}{l}0.078 \\
(0.111)\end{array}$ & $\begin{array}{l}0.088 \\
(0.116)\end{array}$ & $\begin{array}{l}0.089 \\
(0.117)\end{array}$ & $\begin{array}{l}0.089 \\
(0.117)\end{array}$ \\
\hline Retired & $\begin{array}{l}0.131 \\
(0.183)\end{array}$ & $\begin{array}{l}0.167 \\
(0.180)\end{array}$ & $\begin{array}{l}0.169 \\
(0.182)\end{array}$ & $\begin{array}{l}0.170 \\
(0.183)\end{array}$ \\
\hline Log equalized real income & $\begin{array}{l}0.505^{* * *} \\
(0.094)\end{array}$ & $\begin{array}{l}0.366^{* * *} \\
(0.130)\end{array}$ & $\begin{array}{l}0.356^{* 3 *} \\
(0.127)\end{array}$ & $\begin{array}{l}0.352^{* * s} \\
(0.132)\end{array}$ \\
\hline Owner of dwelling & $\begin{array}{l}-0.037 \\
(0.084)\end{array}$ & $\begin{array}{l}-0.086 \\
(0.092)\end{array}$ & $\begin{array}{l}-0.089 \\
(0.093)\end{array}$ & $\begin{array}{l}-0.091 \\
(0.094)\end{array}$ \\
\hline Dwelling needs some renovation & $\begin{array}{l}-0.425^{* * *} \\
(0.070)\end{array}$ & $\begin{array}{l}-0.430^{* * *} \\
(0.074)\end{array}$ & $\begin{array}{l}-0.431^{* * *} \\
(0.074)\end{array}$ & $\begin{array}{l}-0.431^{* * *} \\
(0.074)\end{array}$ \\
\hline
\end{tabular}


Table C.1 (continued)

\begin{tabular}{|c|c|c|c|c|}
\hline Method: & OLS & IV & IV & IV \\
\hline Specification: & (1) & (2) & (3) & (4) \\
\hline Dwelling needs full renovation & $\begin{array}{l}-0.806^{* * *} \\
(0.218)\end{array}$ & $\begin{array}{l}-0.842^{* *+} \\
(0.202)\end{array}$ & $\begin{array}{l}-0.844^{* * *} \\
(0.202)\end{array}$ & $\begin{array}{l}-0.845^{* * 0} \\
(0.203)\end{array}$ \\
\hline Living area & $\begin{array}{l}0.003 \\
(0.003)\end{array}$ & $\begin{array}{l}0.004 \\
(0.003)\end{array}$ & $\begin{array}{l}0.004 \\
(0.003)\end{array}$ & $\begin{array}{l}0.004 \\
(0.003)\end{array}$ \\
\hline Living area squared & $\begin{array}{l}-0.000 \\
(0.000)\end{array}$ & $\begin{array}{l}-0.000 \\
(0.000)\end{array}$ & $\begin{array}{l}-0.000 \\
(0.000)\end{array}$ & $\begin{array}{l}-0.000 \\
(0.000)\end{array}$ \\
\hline Number of persons in household & $\begin{array}{l}0.033 \\
(0.047)\end{array}$ & $\begin{array}{l}0.044 \\
(0.050)\end{array}$ & $\begin{array}{l}0.045 \\
(0.051)\end{array}$ & $\begin{array}{l}0.045 \\
(0.051)\end{array}$ \\
\hline Person needing care in household & $\begin{array}{l}-0.692^{\ldots *} \\
(0.189)\end{array}$ & $\begin{array}{l}-0.794^{\ldots .} \\
(0.200)\end{array}$ & $\begin{array}{l}-0.800^{* * *} \\
(0.200)\end{array}$ & $\begin{array}{l}-0.804^{2 .} \\
(0.202)\end{array}$ \\
\hline No children in household & $\begin{array}{l}0.155 \\
(0.122)\end{array}$ & $\begin{array}{l}0.217 \\
(0.135)\end{array}$ & $\begin{array}{l}0.222 \\
(0.136)\end{array}$ & $\begin{array}{l}0.223 \\
(0.139)\end{array}$ \\
\hline Married & $\begin{array}{l}0.202^{*} \\
(0.117)\end{array}$ & $\begin{array}{l}0.192 \\
(0.119)\end{array}$ & $\begin{array}{l}0.192 \\
(0.120)\end{array}$ & $\begin{array}{l}0.191 \\
(0.120)\end{array}$ \\
\hline Divorced & $\begin{array}{l}0.129 \\
(0.158)\end{array}$ & $\begin{array}{l}0.183 \\
(0.169)\end{array}$ & $\begin{array}{l}0.186 \\
(0.169)\end{array}$ & $\begin{array}{l}0.188 \\
(0.171)\end{array}$ \\
\hline Widowed & $\begin{array}{l}0.423^{*} \\
(0.215)\end{array}$ & $\begin{array}{l}0.481^{*} \\
(0.216)\end{array}$ & $\begin{array}{l}0.485^{* *} \\
(0.217)\end{array}$ & $\begin{array}{l}0.487^{\circ} \\
(0.219)\end{array}$ \\
\hline Separated & $\begin{array}{l}0.471^{*} \\
(0.252)\end{array}$ & $\begin{array}{l}0.350 \\
(0.281)\end{array}$ & $\begin{array}{l}0.343 \\
(0.283)\end{array}$ & $\begin{array}{l}0.339 \\
(0.284)\end{array}$ \\
\hline Partnership & $\begin{array}{l}0.569^{* *} \\
(0.102)\end{array}$ & $\begin{array}{l}0.607^{* 0 .} \\
(0.104)\end{array}$ & $\begin{array}{l}0.610^{*} \\
(0.104)\end{array}$ & $\begin{array}{l}0.611^{* *} \\
(0.104)\end{array}$ \\
\hline Number of doctor visits & $\begin{array}{l}-0.068^{* * *} \\
(0.010)\end{array}$ & $\begin{array}{l}-0.062^{* * *} \\
(0.009)\end{array}$ & $\begin{array}{l}-0.061^{* * *} \\
(0.008)\end{array}$ & $\begin{array}{l}-0.061^{* *} \\
(0.009)\end{array}$ \\
\hline Disability & $\begin{array}{l}-0.178^{\circ} \\
(0.102)\end{array}$ & $\begin{array}{l}-0.132 \\
(0.114)\end{array}$ & $\begin{array}{l}-0.129 \\
(0.114)\end{array}$ & $\begin{array}{l}-0.127 \\
(0.114)\end{array}$ \\
\hline Hospital stay & $\begin{array}{l}-0.250^{\circ *} \\
(0.126)\end{array}$ & $\begin{array}{l}-0.243^{* *} \\
(0.120)\end{array}$ & $\begin{array}{l}-0.243^{* 4} \\
(0.120)\end{array}$ & $\begin{array}{l}-0.242^{* *} \\
(0.120)\end{array}$ \\
\hline Recently married & $\begin{array}{l}-0.291 \\
(0.357)\end{array}$ & $\begin{array}{l}-0.217 \\
(0.377)\end{array}$ & $\begin{array}{l}-0.212 \\
(0.379)\end{array}$ & $\begin{array}{l}-0.210 \\
(0.380)\end{array}$ \\
\hline Recently moved together with partner & $\begin{array}{l}0.040 \\
(0.160)\end{array}$ & $\begin{array}{l}-0.002 \\
(0.166)\end{array}$ & $\begin{array}{l}-0.005 \\
(0.167)\end{array}$ & $\begin{array}{l}-0.006 \\
(0.167)\end{array}$ \\
\hline Recently divorced & $\begin{array}{l}0.537 \\
(0.351)\end{array}$ & $\begin{array}{l}0.696^{*} \\
(0.360)\end{array}$ & $\begin{array}{l}0.706^{*} \\
(0.360)\end{array}$ & $\begin{array}{l}0.711^{*} \\
(0.359)\end{array}$ \\
\hline Recently separated from partner & $\begin{array}{l}-0.291 \\
(0.250)\end{array}$ & $\begin{array}{l}-0.158 \\
(0.269)\end{array}$ & $\begin{array}{l}-0.150 \\
(0.270)\end{array}$ & $\begin{array}{l}-0.146 \\
(0.274)\end{array}$ \\
\hline Recently experienced death of partner & $\begin{array}{l}-2.369^{*} \\
(1.315)\end{array}$ & $\begin{array}{l}-2.144^{*} \\
(1.114)\end{array}$ & $\begin{array}{l}-2.129^{*} \\
(1.102)\end{array}$ & $\begin{array}{l}-2.122^{*} \\
(1.096)\end{array}$ \\
\hline Recently had a child & $\begin{array}{l}0.619^{* * *} \\
(0.154)\end{array}$ & $\begin{array}{l}0.549^{* * *} \\
(0.159)\end{array}$ & $\begin{array}{l}0.544^{* * *} \\
(0.159)\end{array}$ & $\begin{array}{l}0.542^{* k *} \\
(0.162)\end{array}$ \\
\hline Partly oral, partly self-written interview & $\begin{array}{l}0.265^{* *} \\
(0.101)\end{array}$ & $\begin{array}{l}0.166 \\
(0.124)\end{array}$ & $\begin{array}{l}0.159 \\
(0.123)\end{array}$ & $\begin{array}{l}0.156 \\
(0.125)\end{array}$ \\
\hline Self-written without interviewer presence & $\begin{array}{l}0.110 \\
(0.116)\end{array}$ & $\begin{array}{l}0.093 \\
(0.123)\end{array}$ & $\begin{array}{l}0.092 \\
(0.124)\end{array}$ & $\begin{array}{l}0.092 \\
(0.124)\end{array}$ \\
\hline Self-written questionnaire and sent via mail & $\begin{array}{l}0.006 \\
(0.072)\end{array}$ & $\begin{array}{l}0.011 \\
(0.072)\end{array}$ & $\begin{array}{l}0.011 \\
(0.072)\end{array}$ & $\begin{array}{l}0.011 \\
(0.072)\end{array}$ \\
\hline Day of the year & $\begin{array}{c}-0.000 \\
(0.001)\end{array}$ & $\begin{array}{l}-0.000 \\
(0.001)\end{array}$ & $\begin{array}{l}-0.000 \\
(0.001)\end{array}$ & $\begin{array}{l}-0.000 \\
(0.001)\end{array}$ \\
\hline Concerned about the euro & $\begin{array}{l}-0.457^{* * *} \\
(0.107)\end{array}$ & $\begin{array}{l}-1.642^{* *} \\
(0.782)\end{array}$ & $\begin{array}{l}-1.719^{* *} \\
(0.748)\end{array}$ & $\begin{array}{l}-1.756^{* *} \\
(0.773)\end{array}$ \\
\hline Observations & 6436 & 6436 & 6436 & 6436 \\
\hline $\mathrm{R}^{2}$ & 0.206 & 0.142 & 0.133 & 0.129 \\
\hline Kleibergen-Paap Wald F statistic & & 23.870 & 24.473 & 22.107 \\
\hline Further control variables & Yes & Yes & Yes & Yes \\
\hline
\end{tabular}

Notes: dependent variable is life satisfaction on a 0 to 10 scale. Further controls includes variables for federal state (15), weekday of the interview (6) and year in the panel (26). See Table 4 for more information.

$p<.10$.

** $p<.05$.

*** $p<.01$.

\section{References}

Alternative für Deutschland, 2013. Das Wahlprogramm der Alternative für Deutschland. http://www.alternative_rlp.de/wp_content/uploads/2013/05/2013_ Wahlprogramm.pdf.

Angrist, J.D., Pischke, J., 2008. Mostly Harmless Econometrics: An Empiricist's Companion. Princeton University Press, Princeton (N. J.).

Becchetti, L., Clark, A.E., Ricca, E.G., 2011. The value of diplomacy: bilateral relations and immigrant well-being. Paris School of Economics Working Paper No. 11. Berger, E.M., 2010. The Chernobyl Disaster, concem about the environment, and life satisfaction. Kyklos 63, 1-8.

Carroll, N., Frijters, P., Shields, M.A., 2009. Quantifying the Costs of drought: new evidence from life satisfaction data. J. Popul. Econ. 22, $445-461$. 
Chadi, A., 2013. The role of interviewer encounters in panel responses on life satisfaction. Econ. Lett. 121, 550-554.

Chadi, A., 2014. Dissatisfied with life or with being interviewed? Happiness and motivation to participate in a survey. SOEP Papers No. 639.

Clark, A.E., Oswald, A.J., 1994. Unhappiness and unemployment. Econ. J. 104, 648-659.

Conti, G., Pudney, S., 2011. Survey design and the analysis of satisfaction. Rev, Econ. Stat. 93, 1087-1093.

D'Ambrosio, C., Frick, J.R., 2012. Individual wellbeing in a dynamic perspective. Economica 79, 284-302.

Deaton, A., 2012. The financial crisis and the well-being of Americans. Oxf. Econ. Pap. 64, 1-26.

Di Tella, R., MacCulloch, R., 2005. Partisan social happiness, Rev. Econ. Stat. 72, 367-393.

Ferrer-i-Carbonell, A., Frijters, P., 2004. How important is methodology for the estimates of the determinants of happiness? Econ. J. 114, 641-659.

Ferrer-i-Carbonell, A., Gowdy, J.M., 2007. Environmental degradation and happiness. Ecol. Econ. 60, 509-516.

Frey, B., 2008. Happiness. A Revolution in Economics. The MIT Press, Cambridge, MA. and London.

Frey, B.S., Stutzer, A., 2002. Happiness and Economics: How the Economy and Institutions Affect Human Well-being. Princeton University Press, Princeton (N. J.).

Frijters, P., Greenwell, H., Haisken-DeNew, J.P., Shields, M.A., 2009. How well do individuals predict their future life satisfaction? evidence from panel data following a nationwide exogenous shock. Can. J. Econ. 42, 1326-1346.

Frijters, P., Johnston, D., Shields, M., 2011. Life satisfaction dynamics with quarterly life event data. Scand. J. Econ. 113, $190-211$.

Goebel, J., Krekel, C., Tiefenbach, T., Ziebarth, N.R., 2015. How natural disasters can affect environmental concerns, risk aversion, and even politics: evidence from

Fukushima and three European countries, J. Popul. Econ. 28, 1137-1180.

Groseclose, T., Milyo, J., 2005. A measure of media bias. Q. J. Econ. 120, 1191-1237.

Grüner, H.P., 2010. Why EMU is not a failure. Eur. J. Polit. Econ. 26, 1-11.

Hölig. S., Hasebrink, U., 2015. Reuters digital news survey 2015. Ergebnisse für Deutschland. Hans-Bredow-Institut, Hamburg.

mbens, G.W Angrist, J.D. 1994. Identification and estimation of local average treatment effects. Econometrica 62, 467-475.

loannou, D., Stracca, L., 2014. Have the euro area and EU governance worked? Just the facts. Eur. J. Polit. Econ. 34, 1-17.

Isengard, B., Schneider, T., 2007. Attitudes towards the euro: an empirical study based on the German-economic panel (SOEP). Soc. Indic. Res. 82, 35-56.

Janus, A.L., 2010. The influence of social desirability pressures on expressed immigration attitudes. Soc. Sci. Q. 91, 928-946.

Katsimi, M., Moutos, T., 2010. EMU and the Greek crisis: the political-economy perspective. Eur. J. Polit. Econ. 26, 568-576.

Kimball, M., Levy, H., Ohtake, F., Tsutsui, Y., 2006. Unhappiness after Hurricane Katrina. National Bureau of Economic Research, Working Papers 12062.

Knabe, A., Rätzel, S., 2011. Scarring or scaring? The psychological impact of past unemployment and future unemployment risk. Economica 78, 283-293.

Köcher, R., Raffelhüschen, B., 2011. Gluecksatlas Deutschland. Deutsche Post.

Kountouris, Y., Remoundou, K., 2011. Valuing the welfare cost of forest fires: a life satisfaction approach. Kyklos 64, 556-578.

Lamla, M.J., Lein, S.M., 2014. The role of media for consumers' inflation expectation formation. J. Econ. Behav. Organ. 106, 62-77.

Lamla, M.J. Lein, S.M., 2015. Information rigidities, inflation perceptions, and the media: lessons from the euro cash changeover. Econ. Inq. 53, 9-22.

Liberini, F., Redoano, M., Proto, E., 2014. Happy voters. IZA Discussion Paper No. 8498.

Lüchinger, S., 2009. Valuing air quality using the life satisfaction approach. Econ. J. 119, 482-515.

Lüchinger, S., Raschky, P.A., 2009. Valuing flood disasters using the life satisfaction approach. J. Public Econ. 93, 620-633.

McCrae, R.R. Costa, P.T., 1987. Validation of the five-factor model of personality across instruments and observers. J. Pers. Soc. Psychol. 52, 81-90.

Metcalfe, R., Powdthavee, N., Dolan, P., 2011. Destruction and distress: using a quasi-experiment to show the effects of the September 11 attacks on mental well-being in the United Kingdom. Econ. J. 121, F81-F103.

Mikosch, H., Sturm, J.-E., 2012. Has the EMU reduced wage growth and unemployment? Testing a model of trade union behavior. Eur. J. Polit. Econ. $28,27-37$.

Montagnoli, A., Moro, M., 2014. Everybody hurts: banking crises and individual wellbeing. Sheffield Economic Research Paper Series. No. 2014010.

Moro, B., 2014. Lessons from the European economic and financial great crisis: a survey. Eur. J. Polit. Econ. 34, S9-S24.

Oswald, A.J., Powdthavee, N., 2008. Does Happiness Adapt? A Longitudinal Study of Disability with Implications for Economists and Judges. J. Public Econ. 92, 1061-1077.

Powdthavee, N., 2010. How much does money really matter? Estimating the causal effects of income on happiness. Empir. Econ. 39, 77-92.

Routh, D.A., Burgoyne, C.B., 1998. Being in two minds about a single currency: a UK perspective on the euro. J. Econ. Psychol. 19, 741-754.

Schüller, S., 2012. The effect of 9/11 on attitudes towards immigration and the moderating role of education. IZA Discussion Paper No. 7052.

Stephens, M., 2004. Job loss expectations, realizations, and household consumption behavior. Rev. Econ. Stat. 86, 253-269.

Stix, H., 2009. Perceived inflation and the euro: evidence from an Austrian survey. Eur. J. Polit. Econ. 25, 547-561.

Taylor, M.P., 2006. Tell me why I don't like Mondays: investigating calendar effects on job satisfaction and well-being. J. R. Stat. Soc. Ser. A 169, 127-142.

Tsutsui, Y., Kimball, M., Ohtake, F., 2010. Koizumi carried the day: did the Japanese election results make the people happy and unhappy? Eur. J. Polit. Econ. 26, 12-24.

Tumen, S. Zeydanli, T., 2014. Day-of-the-week effects in subjective well-being: does selectivity matter? Soc. Indic. Res. 119, 139-162.

Van Landeghem, B., 2014. A test based on panel refreshments for panel conditioning in stated utility measures. Econ. Lett. 124, $236-238$.

Wagner, G.G., Schräpler, J.-P., 2001. Das Verhalten von Interviewern - Darstellung und ausgewählte Analysen am Beispiel des Interviewer-Panels des Soziooekonomischen Panels. Allg. Stat. Arch. 85, 45-66,

Wagner, G.G., Frick, J.R., Schupp, J., 2007. The German socio-economic panel study (SOEP): scope, evolution and enhancements. J. Appl. Soc. Sci. Stud. 127, 139-169. Ward, G., 2015, Is Happiness a predictor of election results? CEP Discussion Paper No. 1343

Weimann, J., Knabe, A., Schöb, R., 2015. Measuring Happiness: The Economics of Well-being. MIT Press, Cambridge.

Windels, T., Wendler, T., 2014. The European financial crisis: an introduction. Eur. J. Polit. Econ. 34, S1-S2.

Wunder, C., Schwarze, J., Krug, G., Herzog, B., 2008. Welfare effects of the euro cash changeover. Eur. J. Polit. Econ. 24, 571-586. 